\title{
The Relevance of Gender in Tumor-Influencing Epigenetic Traits
}

\author{
Victoria Sarne ${ }^{\mathbb{D}}$, Sandrina Braunmueller, Lisa Rakob and Rita Seeboeck * \\ Department Life Sciences, IMC University of Applied Sciences Krems, 3500 Krems an der Donau, Austria; \\ victoria.sarne@fh-krems.ac.at (V.S.); sandrina.b@gmx.at (S.B.); lisa.rakob@gmx.at (L.R.) \\ * Correspondence: rita.seeboeck@fh-krems.ac.at; Tel.: +43-2732-802263
}

Received: 19 December 2018; Accepted: 24 January 2019; Published: 28 January 2019

\begin{abstract}
Tumorigenesis as well as the molecular orchestration of cancer progression are very complex mechanisms that comprise numerous elements of influence and regulation. Today, many of the major concepts are well described and a basic understanding of a tumor's fine-tuning is given. Throughout the last decade epigenetics has been featured in cancer research and it is now clear that the underlying mechanisms, especially DNA and histone modifications, are important regulators of carcinogenesis and tumor progression. Another key regulator, which is well known but has been neglected in scientific approaches as well as molecular diagnostics and, consequently, treatment conceptualization for a long time, is the subtle influence patient gender has on molecular processes. Naturally, this is greatly based on hormonal differences, but from an epigenetic point of view, the diverse susceptibility to stress and environmental influences is of prime interest. In this review we present the current view on which and how epigenetic modifications, emphasizing DNA methylation, regulate various tumor diseases. It is our aim to elucidate gender and epigenetics and their interconnectedness, which will contribute to understanding of the prospect molecular orchestration of cancer in individual tumors.
\end{abstract}

Keywords: epigenetics; gender medicine; DNA methylation; tumor marker; sex; carcinogenesis; precision medicine

\section{Introduction}

Epigenetic traits, like DNA methylation, can strongly influence a tumor's behavior and vulnerability. So does also patient's gender. Those two fields of research, epigenetics and gender medicine, had a rather exotic standing in oncological research until their importance was clearly shown in the last couple of years [1-4]. Within this review, we aim to give an overview about the most influential aspects of gender medicine and epigenetic DNA methylation on carcinogenesis and tumor development, alluding also to diagnostics and therapy. Furthermore, we feature the crossing points of gender research and epigenetics in order to complete the current view of this promising research area.

Gender medicine has roots in the feminist movement, balancing the well-settled male-dominated view in medicine. But gender medicine is not only about establishing equality among female and male patients; it is also about considering the social gender of an individual. Thus, gender medicine is always individualized medicine, respecting the individual patient's sex, age, ethnicity, education, and social as well as environmental influences. While some implications in oncological processes of, especially biological, gender are well described, many questions still have to be addressed and will find answers considering all aspects of gender. A basic genomic view reveals that while the $Y$ chromosome carries mainly genes associated with sexual function, the $\mathrm{X}$ chromosomes harbor genes coding for physiological processes of the heart, brain and immune system. As a result, women, carrying two copies of the $\mathrm{X}$ chromosome, although one of them is silenced, have a stronger immune system than men, a lower risk for infectious disease and better antibody production following vaccination $[5,6]$. 
On the other hand, women are also more frequently affected by autoimmune disease like multiple sclerosis and rheumatic disease [5,7]. Interestingly, cytochrome p450 isoforms, playing a critical role in drug metabolism and clinical effectiveness, are differentially expressed in female versus male patients $[8,9]$. Lately, an interconnectedness with epigenetics was reported in two independent in vitro studies $[10,11]$. Furthermore, elevated CYP1A1 levels are detected in female lung cancer (LC) patients with a smoking history, correlating to a lower DNA repair capacity and increased risk of developing smoking-related p53 mutations [12]. A significantly higher expression of CYP27B1 was found in tumors of the distal colon in male patients compared to female ones. Rectal tumors, however showed a higher expression of CYP27B1 in women only [13].

In oncology, a gender disparity in incidence, invasiveness as well as the associated prognosis has been observed for various cancer entities. The scientific community gains more and more knowledge, emphasizing that patient gender is still underestimated in clinical practice for the treatment of the major types of cancer.

In mammalian genomes, DNA methylation studies have focused on the covalent addition of a methyl residue to the fifth carbon of a cytosine $(5 \mathrm{meC})$ nucleotide, which is almost exclusively situated $5^{\prime}$ to a guanine nucleotide [14]. Besides, methylation of 5meCpA dinucleotide can also occur in the mammalian genome but is usually restricted to pluripotent cells in embryonic development [15]. DNA methylation triggers chromatin condensation in the dynamic conformation of nucleosomes, which frequently associates with gene silencing [16].

DNA methylation is catalyzed by DNA methyltransferase (DNMT) enzymes which can either maintain methylation or create de novo methylation. In the latter, cytosine-phosphate-guanine (CpG) loci are methylated without the presence of a template strand containing $5 \mathrm{meCpG}$. This process is catalyzed by the methyltransferases DNMT3a and DNMT3b. These enzymes are primarily active during early embryonic development but were also observed in adult mice brain cells to be involved in learning and memory $[17,18]$. In contrast to that, DNMT1 is responsible for maintenance methylation, which takes place on daughter strands after DNA replication and requires the presence of the methylated template to pass the methylation pattern to the next cell generation $[19,20]$.

The presence of physiological differences between males and females is strikingly obvious. Despite that, differences in the epigenome might not be as clear. Even though some studies have reported no difference in the autosomal DNA methylation between genders, a lot of other have found differentially methylated genes (DMGs) as well as differentially methylated CpG sites [21-25].

Generally, a trend towards higher overall methylation in males was found and blood global long interspersed nuclear elements-1 (LINE-1) methylation is also significantly higher in males than in females $[2,5,7-9,26,27]$. If the same is true in disease, whether this has an influence on the response to treatment and disease outcome needs to be further evaluated. Two studies recently investigated differentially methylated CpG sites in the umbilical cord blood of boys and girls. Overall, most differentially methylated CpG sites were more methylated in girls than in boys and when looking at the associated genes, they play a role in nervous system development, brain and heart tissue, as well as behavior [28,29]. Interestingly, not only the differentially methylated regions (DMRs) located on the $\mathrm{X}$ chromosome are methylated to a greater extent, as would be expected due to $\mathrm{X}$ chromosome inactivation, but also autosomal DMRs followed this trend [28]. In adolescents the global methylation level of leukocyte DNA has been found to be significantly higher in females than males [30]. In a reduced representation bisulfite sequencing (RRBS) analysis of human adult liver samples, 460 tiles were differentially methylated and overall, mean methylation was again significantly higher in females compared to males [31]. The analysis of human fetal liver samples, where the fetuses have not been exposed to cigarettes, revealed that DNMT1 expression is higher in males than females, while the opposite is true for the expression of DNMT3B [32]. In concordance with this finding, the expression of DNMT3B was significantly higher in adult liver samples of females than males [33]. Blood DNA of males had lower Alu methylation but higher LINE-1 methylation compared to females [34]. Global methylation was significantly higher in white blood cell DNA of 
females compared to males. Smoking reduced the global methylation in both sexes, even though the effect was stronger in women [35]. The analysis of peripheral blood cells revealed that the promoter region IV of the BDNF gene is significantly more methylated in females than in males [36]. Although several candidate genes have been proposed, a meta-analysis comprising 81 studies found only the gene MGMT to possess significant sex-specific DNA methylation, with all MGMT probes being more methylated in females [25]. Despite that, other studies have reported the opposing trend, MGMT being more methylated in males [22,37]. From the present data it can be concluded that there are, indeed, physiological differences in the epigenome of males and females. Nonetheless, more research is this area is required.

Genomic imprinting is a phenomenon in which epigenetic mechanisms lead to parental-specific gene expression in a diploid cell. This process affects both male and female offspring and is, therefore, considered to be a consequence of inheritance, not sex [38]. Nevertheless, differences between sexes in the DNA methylation of imprinted genes have been found. In a study with a large European cohort, autosomal DNA methylation levels between men and women were compared. The study revealed 1184 CpGs which showed stable DNA methylation differences between sexes. These sites were found to be enriched at imprinted genes [39]. Sex-specific changes in DNA methylation were also found in offspring after suffering nutritional insult during pregnancy [40].

Another important epigenetic factor to consider are histone modifications, which will not be covered in this review. Recent literature includes [41-45].

\section{Gender, DNA Methylation and Cancer}

Worldwide, ranked by incidence as well as mortality, LC is the most common cancer [46,47]. In terms of incidence, LC is followed by breast cancer (BC), colorectal cancer (CRC) and cancers of prostate, stomach and liver. These six cancer entities together represent more than half of the global incidences in 2018. As for mortality, LC alone is responsible for $18.4 \%$ of 2018th tumor deaths, followed by CRC, stomach, liver and BC $[46,47]$. Gender-specific differences in incidence, progression, treatment and survival have been reported for a variety of cancer types, hence the most common types of cancer differ between sexes. In men, the five most common cancers are: lung, prostate, colorectal, stomach, and liver. In women the most common cancer is breast, followed by colorectal, lung, cervix uteri and stomach. In cancers affecting both genders, a general higher risk as well as absolute number of incidences and deaths accounts for the male population, although there is great variance among specific entities and geographical regions [46,47].

In this review we focus on solid tumors. As for hematological malignancies we recommend the review by Ben-Batalla et al. published in late 2018, which discusses the sexual dimorphism in non-solid cancer in more depth than the scope of this review allows [48].

Aberrant epigenetic regulation is known to directly contribute to disease specific phenotypes. In this fashion, epigenetic changes are involved in carcinogenesis and the development of tumor disease [49]. Among other epigenetic mechanisms, DNA methylation seems to play a particularly important role in the initiation and progression of cancer. Cancer cells often display methylation patterns that differ from their non-cancerous counterparts [1]. Both hyper- and hypo-methylation have been proposed to be important events in carcinogenesis and immune signaling in tumor tissue [50]. As described above, hypermethylation of cytosine in CpG islands (CGIs) by DNMTs of promoter regions has been shown to enable gene repression. Therefore, hypermethylation in tumor suppressor genes (TSGs) potentiates tumorigenic activity due to the disruption of critical cellular processes like cell cycle control, DNA repair and apoptosis [51-53].

Even though it is well established that epigenetic modifications play a role in cancer progression in many different types of cancers and are even thought to drive metastasis, there is only little information available about gender-associated differences in epigenetic patterns within the different cancer types [54-60]. Epigenetic inactivation can be viewed as an alternative to genetic mutations in cancer [61]. The change in phenotype subsequently facilitates the adaption of cancer cells to their 
specific environments [61]. In fact, it has been suggested that heritable losses of gene function may be mediated as often by epigenetic as by genetic abnormalities [62,63]. Looking at the vast amount of data available, it is becoming increasingly apparent that instead of cancer being either a genetic or epigenetic disease, the synergy between these two processes drives tumor progression from the earliest to latest stages of disease [64]. A prominent example is KRAS mutation upon epigenetic stimulation triggered by long-term exposure of cells to cigarette smoke [65]. These changes include initial repressive polycomb marking of genes, followed by the later manifestation of aberrant DNA methylation. Epigenetic changes may, therefore, potentially prime cells for oncogene addiction [66].

Several studies have identified a variety of DMRs in different cancers. Specific DMRs have been proposed to not only be tumor specific, but also subtype specific. Subsequently, DNA methylation profiling has confirmed the existence of epigenetic subtypes in cancers. In this fashion, specific methylation profiles of LC samples identified subtypes of tumors with distinct prognoses [50]. Similarly, a differentiation between tumor and control lung tissue, as well as identification of novel DMRs for the two most common non-small cell LC (NSCLC) subtypes, adenocarcinomas and squamous cell carcinoma is reported based on methylation patterns [67]. DNA methylation subgroups, referred to as epitypes, may discriminate between tumor subtypes like neuroendocrine tumors (SCLC and LCNEC) and adenocarcinoma [50,67-69].

Lung cancer is of prime interest for gender research, as it is strongly influenced in pathogenesis as well as progression by hormones and the mutational status of their receptors and possesses several further gender-dependent characteristics. Global as well as national reports show a dramatic, gender specific change in LC incidences and death rates [70-73]: while historically men were more frequently affected by LC, the number of women suffering from LC is increasing quickly, i.e., by $30 \%$ in the last 10 years in the exemplary Austrian population [72]. At the same time, mortality rates are increasing for women only, which indicates dramatically that LC treatment is obviously a gender topic [72]. Also, in tumor subtypes gender-differences are known, NSCLC is more common in men, however there was an increase in the proportion of women $<55$ years that has manifested throughout the last decade. Adenocarcinoma is rather predominant in women, while squamous cell carcinoma (SCC) is more likely to develop in men $>72$ years [74]. Smoking is the major risk factor for developing LC, therefore the male to female ratio of relative risk (RRR) was found to be 1.61 compared to non-smokers in a meta-analysis of 47 publications. Currently smoking men have a higher risk of developing LC than women, regardless of smoking quantity and duration or years since quitting [75]. Interestingly, the absolute risk of LC in never smokers was higher in women than in men, while smoking men have a higher risk of developing LC compared to smoking women [76].

\subsection{Hormonal Influences, Microsatellite Instability (MSI) and Chromosomal Instability}

Reasons for carcinogenic differences between female and male LC patients are not clear. In LC it was found that progesterone receptor (PR) expression in tumor stromal cells correlated with improved disease-specific survival (DSS) for both genders, while PR expression in tumor epithelial cells was associated with poor prognosis in females only and could therefore be used as prognostic biomarker [77]. An important role in the pathogenesis of NSCLC is taken over by estrogens; its receptor, estrogen receptor (ER) $\beta$ is predominantly found in ovary and lung tissue and ER $\alpha$ is rather found in breast, ovary and endometrial tissues [78]. ER $\beta$ is expressed in NSCLC tumors of both sexes, whereas a higher level was found in male individuals. More precisely, women were $46 \%$ less likely to have ER $\beta$-positive tumors than men [79]. Estrogen signaling causes proliferation in NSCLC cell lines, and recently progesterone, was found to be expressed in correlation with cell proliferation. In combination, these two stimulate vascular endothelial growth factor secretion in vitro, and thereby promote cancer-associated angiogenesis and tumor progression [80]. ER $\alpha$ is significantly more methylated in males than in females suffering from LC [81]. Considering chromosomal instability, polymorphisms of GSTT1 and GSTM1, two Glutathione S transferases important for detoxification, were found to result in an increased LC risk. Specifically, the GSTT1 null genotype was associated 
with an increased risk in men only, while GSTM1 null genotype lead to an increased risk in female subjects [82]. Another marker for NSCLC is EML-ALK4. This fusion oncogene was found to be associated preferentially with male gender, never/light smoking behavior and younger age [83]. The clinically most important marker to date is the mutational status of the epidermal growth factor receptor (EGFR), which is a glycoprotein found in high density on the NSCLC cell surface, genetic mutations of which result in uncontrolled stimulation of cell proliferation. Those mutations are found at higher frequency in women [84]. This fact was also confirmed in the Iressa Pan Asia Study (I-PASS), where EGFR tyrosine kinase inhibitor (TKI) therapy was confirmed [85].

Dependencies on estrogen and androgen are major gender-associated factors, influencing essentially all tumor entities. In CRC AR, ER $\alpha$ and $E R \beta$, together with the membrane receptors of growth-inhibiting melatonin MT1 and MT2, were observed to be downregulated in the early stage and advanced tumors in male patients only [86]. The overall expression of MT1 and MT2 correlated positively with AR, ER $\alpha$ and ER $\beta$ in men and with ER $\alpha$ and ER $\beta$ in women [86]. Aggressive, right-sided colon cancer is frequently associated with microsatellite instability (MSI), which might develop at an increased risk in older women due to a lack of estrogen hormone and can be counteracted by hormone replacement therapy [87]. $h M L H 1$, which is analyzed for MSI is, together with $p 14^{A R F}$, significantly more methylated in female than in male CRC patients [88,89]. Genetic differences were found in CRC patient samples analyzing chromosomal copy number aberrations, were female gender associated with significantly higher numbers of gains in chromosome arms 1p21.2-q21.3, 4q13.2, 6q11.2 and decreased copy numbers of 11q25. Almost half of the male samples displayed a "feminization" phenomenon, as they gained a whole or an arm of an X chromosome and/or lost the Y chromosome. This phenomenon was associated with microsatellite-stable CRCs and wild-type BRAF cancers [90]. A link between androgen receptor (AR) status, poor survival and the expression of TUBB3/TUBB6 was identified in female CRC samples only. In males, however, there was no relationship between TUBB3/TUBB6 expression and the outcome and aggressiveness of cancer [91].

In gastric cancer (GC), MSI is also more common in females and mutated samples [92]. Generally, it is suggested that the presence of estrogens protects females from GC, and hence there is an increase in incidence after the menopausal age [93]. The protective effects of estrogen were also suggested for H. pylori-associated GC [94].

In hepatocellular carcinoma (HCC), the incidence rate of male:female patients is approximately 3:1 and was traditionally explained by a gender-dependent differences in exposure to risk factors, such as higher HBV and HCV infection rates amongst males, as well as higher alcohol consumption, smoking behavior and increased iron stores [95]. However, more recent studies emphasize that androgens influence HCC progression and, therefore, might be responsible for the dimorphism, rather than sex-specific risk factor exposure. In this manner, non-environmental endogenous factors might play a role in male susceptibility to HCC, such as higher body mass index (BMI) and higher levels of androgenic hormones [95]. This scheme is further supported by the observation that chronic liver disease progresses into cirrhosis more rapidly in males and therefore leads to HCC development faster [96]. Sex hormones and their receptors were found to greatly contribute to the gender disparity in inflammation-driven HCC. Generally, androgens were found to exert tumor-promoting functions, whereas estrogens were found to possess tumor-inhibiting potential [97].

$\mathrm{BC}$ is a clear gender-dependent tumor entity with only $1 \%$ of all $\mathrm{BC}$ cases in the US being male BC (MBC) [98]. Nevertheless, sex specific differences in clearance, general incidence rates as well as pathology have been reported [99]. Looking at pharmacokinetics, it was found that the clearance of the chemostatic drug Doxorubicin was significantly higher in male patients, compared to females, which could be due to epigenetic regulation of cytochrome family members [100].

$B C$ with $B R C A 1$ or, more commonly, $B R C A 2$ mutations differs in its pathological characteristics between $\mathrm{MBC}$ and female breast cancer (FBC). BRCA2 mutated MBC was suggested to possess generally greater biological aggressiveness [101]. The biology of $\mathrm{MBC}$ is thought to resemble late-onset 
FBC. However, MBC was also found to occur later in life and with a higher proportion of $E R$ positive and $P R$ positive tumors [102].

In familial BC, similarly to LC, males shower higher levels of global hypermethylation than the female cohort [103]. In a recent in-vitro study female hormone-free, ER-/PR- positive BC cells were assessed and revealed a dependency of ER $\alpha$ expression on PR expression. PR was shown to directly bind ESR1 locus preserving a low DNA methylation and expression of E $\alpha$ [104]. This mechanism emphasizes the strong impact of $\mathrm{ER} \alpha$ promoter methylation status on endocrine therapy and identifies it as a valuable predictive biomarker.

Furthermore, there was also a correlation between ER status and RASSF1A methylation. Males showed higher methylation of RASSF1A when the ER was not mutated, while females showed higher promoter hypermethylation levels concurrent with $E R$ mutation [103].

\subsection{RASSF1 and MGMT and Further Differentially Methylated Genes (DMGs)}

The aforementioned RASSF1 is a putative tumor suppressor and a major target of tumor-associated epigenetic dysregulation. It mediates death receptor-dependent apoptosis and contributes to the efficient activation of TP53 by disrupting MDM2 interactions and promoting MDM2 self-ubiquitination in cell-cycle checkpoint control, triggered by DNA damage [105]. Generally, mRNA expression of RASSF1 transcripts is often lost in LC, where methylation was identified as the major mechanism silencing this gene, while mutations are rare [106]. The promoter region of RASSF1A is frequently hypermethylated in many types of cancers [107-110]. However, only in recent years it was investigated whether gender played a role in methylation frequency of RASSF1A. It was found that promoter hypermethylation of RASSF1A was higher in male LC patients than in female patients [111]. By contrast, female CRC patients showed significantly higher promoter hypermethylation of RASSF1A, than males [112].

$\mathrm{O}^{6}$-methylguanine-DNA methyltransferase (MGMT) repairs DNA lesions caused by alkylating agents and prevents cell death. As a result, the methylation and consequent loss of MGMT expression leads to less repair and increased sensitivity of tumor cells towards alkylating drugs. Methylated promoter methylation indicates a significant survival benefit of patients treated with radiotherapy and temozolomide [113]. Determination of MGMT promoter methylation is widely used in clinical routines as a predictive biomarker to assess treatment prospects of glioblastoma with the alkylating agent temozolomide [113]. In LC male non-smokers show a higher frequency of MGMT promoter hypermethylation than female nonsmokers. Furthermore, $p 53$ mutated tumors showed higher levels of MGMT methylation in males than $p 53$ wild-type tumors [37].

Again, contrasting MGMT promoter hypermethylation was found to be significantly higher in females than males in a Taiwanese CRC patient cohort [114]. In gastric cancer, also females also showed a higher rate of promoter methylation of MGMT together with $h M L H 1$ and GSTP1 than males [115].

Apart from the gender differences basted on hormonal signaling and receptor expression, we showed that chromosomal instability, as well as the differential methylation of RASSF1 and MGMT are epigenetic tumormarkers, affecting a broad range of entities. In the following we summarize epigenetic marker genes that are under research or approaching clinical implications for selected or general application in various solid tumors.

In LC, DNA methylation patterns of a number of additional genes have been found to have been altered in cancer tissue [65,116-123]. TSGs such as RASSF1, CDKN2A,DAPK, APC and $p 14^{A R F}$ are aberrantly methylated in NSCLC as well as other cancers, namely head and neck cancer (HNC), prostate cancer and cervical cancer [124-132].

Genes that are tumor specifically methylated in LC, specifically NSCLC, further include SPAG6 and L1TD1. The methylation was also shown to be involved in the transcriptional regulation in these genes. L1TD1 additionally has been shown to have tumor growth-suppressing properties and seems to be universally methylated and thereby downregulated in NSCLC [133]. 
Furthermore, several other known and putative TSGs have been identified that are involved in the pathogenesis of LC and are frequently inactivated by methylation $[120,122,134,135]$. Namely, methylation was identified as underlying mechanism for the reported frequent RAR $\beta$ expression in NSCLC [136-138].

A candidate TSG, FHIT was found to be frequently abnormal in LC, and recently reported to also be frequently methylated in primary NSCLC [139-141]. $p 16^{I N K 4 a}$ also has been reported to frequently be inactivated by methylation in NSCLC, and even linked to an early stage in the pathogenesis of LC $[120,124]$.

Aberrant $A N K 1 B$ methylation is highly prevalent in LC and allows the discrimination of tumors by histology and patients' smoking history: Aberrant $A N K 1 B$ promoter methylation was significantly more prevalent in current and former smokers combined than in never smokers [142].

ZNF677 was found to be tumor-specifically downregulated by methylation and suggested to have cell growth-suppressing properties in NSCLC [134]. Besides, it was reported that methylation is the major mechanism for inactivating CDH13 [143]. ZAR1 has also been shown to be inactivated by DNA methylation specifically in lung tumors [144]. A study comparing neuroendocrine tumors with NSCLC found, that $p 16^{I N K 4 a}, A P C$ and CDH13 methylation was higher in NSCLC [65]. Additionally, it was found that $p 16^{I N K 4 a}$ was generally more frequently methylated in NSCLC compared to SCLC [65]. Furthermore, apart from the possible discrimination between tumor types, genes that are differentially methylated between tumors of smokers and never-smokers have been identified [117,145]. Genes, which were found to be differentially methylated, are LGALS4, CXorf38, MTHFD2, TLL2, ALPPL2, GFI1, MYO1G, AHRR, ZNF385D, IER3 and F2RL3 [117,145,146]. Differential DNA methylation has also been identified as a marker for prenatal smoke exposure in adults [147].

In a CRC, the TSG $p 16^{I N K 4 a}$ was found to be differentially methylated in males and females [148]. Here, females show significantly higher methylation, as the methylation of the CGI $5^{\prime}$ of the $p 16^{I N K 4 a}$ tumor suppressor was found to be 8.8-fold more likely hypermethylated in women than in male subjects. Generally, CGI methylation extent was shown to increase from the rectum to the cecum, where women had a higher percentage of developing tumors in the cecum [148-150]. In addition, the female gender is associated with CGI methylator phenotype (CIMP) high status in CRC according to two studies [151,152]. Different cancers show different TSG-inactivating DNA methylation profiles and frequencies $[153,154]$. The concept of CIMP was originally introduced by Toyota et al., in 1999 and describes the synchronous hypermethylation of multiple gene promoter regions [155]. Since then, CIMP has been reported in various types of cancers, including NSCLC and CRC [155,156].

In NSCLC specifically, chromosome 3p-specific CIMP is a frequent epigenetic event [157]. CIMP status and survival prognosis of NSCLC have also been linked [157]. In this manner, adenocarcinoma cases with CIMP have a poorer prognosis than adenocarcinoma cases without CIMP [156]. CIMP status and prognosis have also been linked in CRC [155].

In GC, the mRNA expression and protein expression of DNMT1 is significantly higher in males than in females, which suggests the presence of epigenetic differences between the sexes [158,159]. Accordingly, the promoter hypermethylation of HACE 1 and HOXA11 was significantly higher in males than in females suffering from GC $[160,161]$. Furthermore, it was found that in chronic gastritis patients' methylation of DAPK, CDH1, THBS1, and TIMP-3 is higher in males than females [162]. On the other hand, LINE-1 methylation was higher in female GC patients compared to males [163].

HCC also showed different methylation patterns between the two sexes. The CIMP high type was significantly more frequent in male patients compared to female patients. However, when looking at the gender specific methylation of $p 16^{I N K 4 A}$ contradictory conclusions have been drawn. In one study, $p 16^{I N K 4 A}$ promoter methylation was significantly higher in males than females with HCC, while in another study $p 16^{I N K 4 A}$ promoter methylation was significantly higher in females than males. [164,165].

Table 1 gives an overview of genes that are reportedly differentially methylated in tumors. We verified the impact by comparison with data in the TCGA genomic data commons data portal (https://portal.gdc.cancer.gov) to verify mutational status and especially gender differences, and with 
methylation data of MethHC (https:/ / methhc.mbc.nctu.edu.tw), where differential methylation across tumor entities is deposited. Consequently, the given references are only representative, evidence-based documents of the genes' epigenetic and gender impact.

Table 1. Aberrantly methylated genes of various tumor types and reported gender difference.

\begin{tabular}{|c|c|c|}
\hline Gene & Cancers & Reported Gender Difference \\
\hline ANK1 & Pancreatic cancer [166], lung cancer (LC) [142] & \\
\hline$A P C$ & Melanoma [167], Nasopharyngeal carcinoma [168], LC [65] & \\
\hline CDH1 & $\begin{array}{l}\text { Breast cancer (BC) [169], Cervical cancer [127], Head and neck cancer (HNC) [125], LC [65], } \\
\text { Oral cancer [170], GC [162] }\end{array}$ & GC [162] \\
\hline CDH11 & Melanoma [171] & \\
\hline $\mathrm{CDH13}$ & BC [143], CRC [172], LC [65], Melanoma [167], Prostate Cancer [173] & LC [174] \\
\hline CLDN11 & Melanoma [171] & \\
\hline COL1A2 & Melanoma [171] & \\
\hline$D A P K$ & $\begin{array}{l}\text { Cervical cancer [127], HNC [125], LC [130], Nasopharyngeal carcinoma [168], Prostate } \\
\text { Cancer [173], Gastric cancer (GC) [162] }\end{array}$ & GC [162] \\
\hline EGFR & BC [175], LC [176] & \\
\hline$E R \alpha$ & LC [81] & LC [81] \\
\hline ESR1 & LC [174] & LC [174] \\
\hline FHIT & BC [141], Cervical cancer [177], Liver cancer [178], LC [141] & \\
\hline GATA5 & LC [174] & LC [174] \\
\hline GSTP1 & GC [115] & GC [115] \\
\hline HACE1 & GC [160] & GC [160] \\
\hline hMLH1 & BC [169], LC [179], Colorectal cancer (CRC) [88] GC [115] & CRC [88], GC [115] \\
\hline HOXA11 & GC [161] & GC [161] \\
\hline HOXA9 & Melanoma [171] & \\
\hline KCNH8 & LC [180] & LC [180] \\
\hline L1TD1 & LC [133] & \\
\hline LOX & Melanoma [171] & \\
\hline MAPK13 & Melanoma [171] & \\
\hline MGMT & CRC [112], LC [37], GC [115] & LC [37], GC [115] \\
\hline MGMT & LC [37], Glioblastoma [181] & LC [37], CRC [114] \\
\hline p14(ARF) & CRC [89] & CRC [88] \\
\hline p16INK4a & BC [169], Cervical cancer [127], HNC [125], LC [65], Melanoma [167], Prostate Cancer [173] & CRC [148], HCC [164,165] \\
\hline PAX6 & LC [174] & LC [174] \\
\hline PTEN & Melanoma [171] & \\
\hline RARß & LC [65], Melanoma [167], Oral cancer [170], Prostate cancer [126] & LC [180] \\
\hline RASSF1 & $\begin{array}{c}\text { BC [169], Endometrial cancer [182], LC [65], Melanoma [167], Nasopharyngeal carcinoma } \\
\text { [168], Oral cancer [170], Prostate Cancer [173], CRC [112] }\end{array}$ & CRC [112], LC [111], BC [103] \\
\hline RNF & LC [183] & \\
\hline SPAG6 & LC [133] & \\
\hline SYK & Melanoma [171] & \\
\hline THBS1 & GC [162] & GC [162] \\
\hline TIMP3 & GC [162] & GC [162] \\
\hline TNFSF10D & Melanoma [171] & \\
\hline ZAR1 & Bladder cancer [184], Cervical cancer [185], LC [144] & \\
\hline ZNF677 & LC [134] & \\
\hline
\end{tabular}

\section{DNA Methylation as Prognostic Marker}

Apart from the fact that tumor specific methylation profiles could aid the early detection of NSCLC and other cancers like prostate and cervical cancer in the future, DNA methylation has additionally been linked with prognosis in NSCLC [126,135,186,187]. Consequently, several studies have suggested that the presence of DNA hyper-methylation in NSCLC might be associated with progression, recurrence and long-term-survival [53,157].

A study comparing low- and high-metastatic NSCLC cells, high metastatic cells showed lower methylated RNF promoters and, accordingly, lower RNF111 transcriptional expression levels. RNF affects TGF-/Smad signaling and is associated with invasion in NSCLC [183].

Furthermore, $p 16^{I N K 4 a}$ methylation was associated with significantly poorer survival, whereas CDH1 methylation was associated with significantly better survival in a previous study. The same study also showed that the hypermethylation of multiple genes exhibited a significant differential effect on NSCLC patient survival [123].

The presence of methylation on the promoter region of four genes in particular ( $p 16^{I N K 4 a}, C D H 13$, RASSF1 and APC) in patients with early stage NSCLC that was treated by means of surgery has been associated with early recurrence [187]. Patients with methylated ZNF677 was associated with shorter overall survival compared to patients with unmethylated ZNF677 [134]. 
hMLH1 methylation was identified as a common event in NSCLC and may aid in the prediction of recurrence and metastasis of NSCLC patients who accepted post-operative adjuvant cisplatin-based chemotherapy. Therefore, $h M L H 1$ methylation is considered a biomarker of individualized therapy for NSCLC $[179,188]$.

EGFR gene methylation was found to not be influenced by age, gender or smoking status of the patient, but rather found to increase with later stages. EGFR methylation may, therefore, be used as an indicator for the stage of cancer tissue malignancy [176].

Patients with early stage NSCLC are still at considerable risk of recurrence and death, even after complete surgical resection. Candidate DNA methylation biomarkers were identified allowing patients at low risk of relapse and those at high risk to be distinguished, which could aid in the decision-making process of further treatment [135].

Among the already identified and routinely implemented epigenetic marker genes is the programmatic promoter DNA methylation of the DNA repair gene MGMT in the treatment of glioblastoma by temozolomide (an alkylating agent) [181,189]. MGMT repairs the lesion caused by temozolomide and, thereby, prevents the induction of cell death. Methylation and loss of expression of MGMT leads to less repair coupled to increased sensitivity of cells to the alkylating agent. Clinical studies showed that glioma patients treated with temozolomide and radiotherapy who have a methylated MGMT promoter have a significant survival benefit compared to radiotherapy only. At the same time, lack of MGMT promoter methylation reset the prognostic advantage to an absence of significant differences between treatment groups [189].

\section{Epigenetic Mechanisms as Drug Targets}

Targeting epigenetic mechanisms in the treatment of NSCLC and other cancers has been proposed. The metastatic capability of NSCLC is closely associated with DNA methylome alterations [190]. The metastasis-prone phenotype could be reversed in vitro by inhibiting DNMT. Due to this fact, epigenetic modulation seems to be a potential therapeutic approach to prevent metastasis formation [190].

Further information about epigenetic therapies in LC can be found in the recent reviews of Schiffman or Carter [51,191]. Among the currently five different epigenetic agents approved by the United States Food and Drug Administration (FDA), two are DNMT inhibitors and three HDAC inhibitors [192]. The DNMT inhibitors have been shown to possess clinical utility on the treatment of myelodysplastic syndrome and leukemia, whereas the HDAC inhibitors are used in the treatment of rare cutaneous T-cell lymphoma [193]. However, this first generation of epigenetic inhibitors has only shown limited utility due to toxicity and off-target effects $[192,194]$. In solid tumors, epidrugs have shown very modest anti-tumor efficacy in monotherapy as well was in combination with other therapies. Nevertheless, further generations of epidrugs still are considered promising in advancing cancer treatment.

Only recently, clustered regularly interspaced short palindromic repeat (CRISPR) technology became applicable for the development and in-vitro testing of epidrugs. When introducing epigenetic marks, i.e., DNA methylation patterns as prognostic or predictive tumormarkers, a solid understanding of the molecular background is needed. In 2016 for the first time the CRISPR- associated protein 9 (Cas9) based DNA methylation editing tools were published and kicked off a new era of epigenetic research $[195,196]$. The CRISPR/Cas9 system was originally identified as a natural immune defense system in bacteria and is now famously implemented in molecular biology translational research as a site-specific genome editing tool. In the case of epigenetic editing, the aim is selectively to modify epigenetic marks, e.g., CpG methylation at a targeted locus. To achieve CRISPR/Cas9-mediated epigenome editing, the main strategy is fusing an inactivated Cas9 protein with an epigenetic effector (epieffector) domain [197]. Inactivation of Cas9 $\rightarrow$ dCas9 leads to a protein that no longer has nuclease activity but a stable DNA binding domain, that can be targeted using sgRNAs. There are 
various options for epieffector domains, including VPR/VP64 transactivation domains, the DNA demethylating TET domain or DNMT3A domain [195,196,198,199].

\section{Conclusions}

DNA methylation and patient gender are two general parameters of carcinogenesis and tumor progression. Although there is no doubt about their impact, the underlying availability of solid data is limited. We have put together the currently available literature on this cross-sectional research field, showing a strong implication of patient gender and growing evidence of epigenetic tumormarkers for disease prediction as well as prognosis. It has also become clear that gender-dependent differences in carcinogenesis may be interlinked to epigenetic mechanisms that are themselves dependent on the underlying patient's biological sex and environmental influences. Today, only MGMT promoter methylation is comprehensively implemented in molecular diagnostics, but there are numerous biomarkers in the pipelines to clinical implications. We hope that we can raise awareness for the strong influence of patient gender to be considered at any stage from tumor diagnostics over monitoring therapy design to make epigenetic medicine a truly personalized medicine from the start.

Author Contributions: Conceptualization, R.S.; writing—original draft preparation, L.R. and S.B.; writingreview and editing, V.S. and R.S.

Funding: This research was funded by Österreichische Forschungsförderungsgesellschaft; Programm Talente, FEMtech Forschungsprojekte; .FFG Austria, grant number 849800.

Conflicts of Interest: The authors declare no conflict of interest.

\section{List of Abbreviations}

$\begin{array}{ll}\text { AR } & \text { Androgen receptor } \\ \text { BC } & \text { Breast cancer } \\ \text { CGI } & \text { CpG island } \\ \text { CIMP } & \text { CpG island methylator phenotype } \\ \text { CpG } & \text { Cytosine-phosphate-guanine } \\ \text { CRC } & \text { Colorectal cancer } \\ \text { DMR } & \text { Differentially methylated regions } \\ \text { DNMT } & \text { DNA methyltransferase } \\ \text { DSS } & \text { Disease specific survival } \\ \text { EGFR } & \text { Epidermal growth factor receptor } \\ \text { ER } & \text { Estrogen Receptor } \\ \text { FBC } & \text { Female breast cancer } \\ \text { GC } & \text { Gastric cancer } \\ \text { HCC } & \text { Hepatocellular carcinoma } \\ \text { HNC } & \text { Head and neck cancer } \\ \text { I-PASS } & \text { Iressa Ran Asia Study } \\ \text { LC } & \text { Lung cancer } \\ \text { LINE-1 } & \text { Ling interspersed nuclear elements-1 } \\ \text { MBC } & \text { Male breast cancer } \\ \text { NSCLC } & \text { Non-small cell lung cancer } \\ \text { PR } & \text { Progesterone receptor } \\ \text { RRBS } & \text { Reduced representation bisulfite sequencing } \\ \text { RRR } & \text { Ratio of relative risk } \\ \text { SCC } & \text { Squamous cell carcinoma } \\ \text { TKI } & \text { Tyrosine kinase inhibitor } \\ \text { TSG } & \text { Tumor suppressor gene } \\ \text { AHRR } & \text { aryl-hydrocarbon receptor repressor } \\ \text { ALPPL2 } & \text { alkaline phosphatase } \\ \text { ANK1 } & \text { ankyrin 1 } \\ & \end{array}$




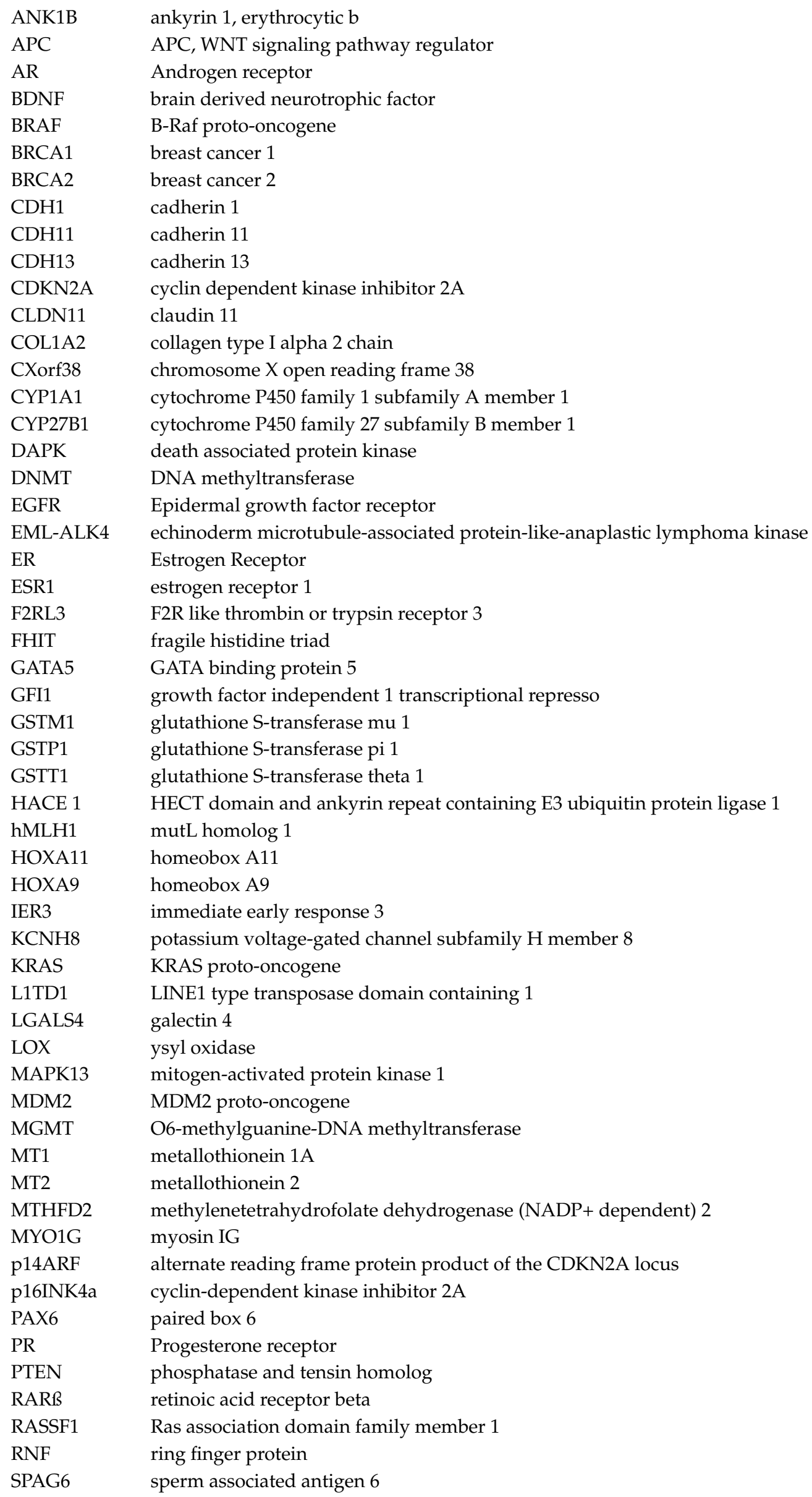




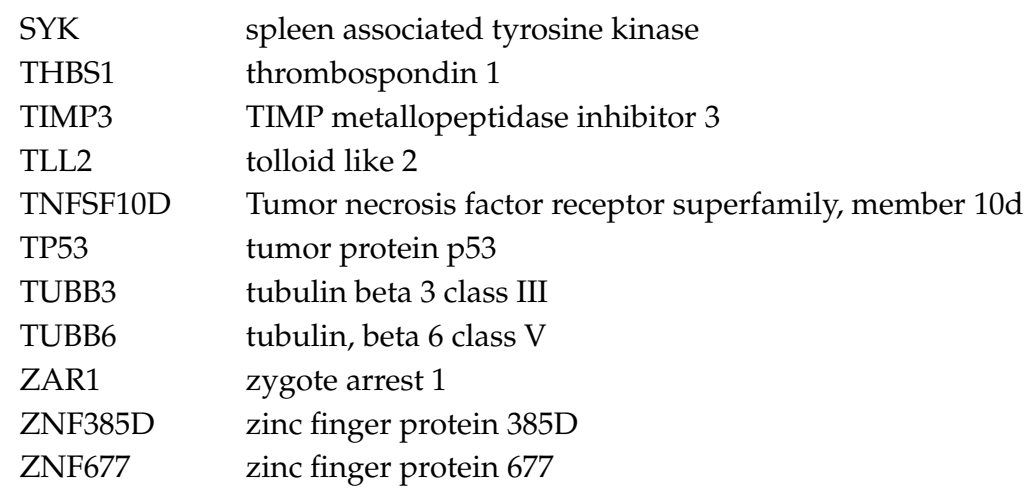

\section{References}

1. Sharma, S.; Kelly, T.K.; Jones, P.A. Epigenetics in cancer. Carcinogenesis 2010, 31, 27-36. [CrossRef] [PubMed]

2. Zhang, F.F.; Cardarelli, R.; Carroll, J.; Fulda, K.G.; Kaur, M.; Gonzalez, K.; Vishwanatha, J.K.; Santella, R.M.; Morabia, A. Significant differences in global genomic DNA methylation by gender and race/ethnicity in peripheral blood. Epigenetics 2011, 6, 623-629. [CrossRef] [PubMed]

3. Moynihan, C. Men, women, gender and cancer. Eur. J. Cancer Care Engl. 2002, 11, 166-172. [CrossRef] [PubMed]

4. Dorak, T.M.; Karpuzoglu, E. Gender differences in cancer susceptibility: An inadequately addressed issue. Front. Genet. 2012, 3, 268. [CrossRef] [PubMed]

5. Kautzky-Willer, A. Gendermedizin; UTB GmbH: Stuttgart, Germany, 2012; p. 280.

6. Dorner, T.E.; Ràsky, E.; Stein, K.V.; Stronegger, W.J.; Kautzky-Willer, A.; Rieder, A. Coverage of recommended vaccinations in subjects with diabetes mellitus and ischemic heart disease: Results for women and men. Wien Med. Wochenschr. 2011, 161, 136-142. [CrossRef] [PubMed]

7. Baggio, G.; Corsini, A.; Floreani, A.; Giannini, S.; Zagonel, V. Gender medicine: A task for the third millennium. Clin. Chem. Lab. Med. 2013, 51, 713-727. [CrossRef]

8. Scandlyn, M.J.; Stuart, E.C.; Rosengren, R.J. Sex-specific differences in CYP450 isoforms in humans. Expert Opin. Drug Metab. Toxicol. 2008, 4, 413-424. [CrossRef]

9. Mittal, B.; Tulsyan, S.; Kumar, S.; Mittal, R.D.; Agarwal, G. Cytochrome P450 in Cancer Susceptibility and Treatment. Adv. Clin. Chem. 2015, 71, 77-139.

10. Nakamura, K.; Aizawa, K.; Aung, K.H.; Yamauchi, J.; Tanoue, A. Zebularine upregulates expression of CYP genes through inhibition of DNMT1 and PKR in HepG2 cells. Sci. Rep. 2017, 7, 41093. [CrossRef]

11. Penaloza, C.G.; Estevez, B.; Han, D.M.; Norouzi, M.; Lockshin, R.A.; Zakeri, Z. Sex-dependent regulation of cytochrome P450 family members Cyp1a1, Cyp2e1, and Cyp7b1 by methylation of DNA. FASEB J. 2014, 28, 966-977. [CrossRef]

12. Donington, J.S.; Colson, Y.L. Sex and gender differences in non-small cell lung cancer. Semin. Thorac. Cardiovasc. Surg. 2011, 23, 137-145. [CrossRef]

13. Brozek, W.; Manhardt, T.; Kállay, E.; Peterlik, M.; Cross, H.S. Relative Expression of Vitamin D Hydroxylases, CYP27B1 and CYP24A1, and of Cyclooxygenase-2 and Heterogeneity of Human Colorectal Cancer in Relation to Age, Gender, Tumor Location, and Malignancy: Results from Factor and Cluster Analysis. Cancers 2012, 4, 763-776. [CrossRef]

14. Holliday, R.; Pugh, J.E. DNA modification mechanisms and gene activity during development. Science 1975, 187, 226-232. [CrossRef]

15. Ziller, M.J.; Müller, F.; Liao, J.; Zhang, Y.; Gu, H.; Bock, C.; Boyle, P.; Epstein, C.B.; Bernstein, B.E.; Lengauer, T.; et al. Genomic distribution and inter-sample variation of non-CpG methylation across human cell types. PLoS Genet. 2011, 7, e1002389. [CrossRef]

16. Jimenez-Useche, I.; Yuan, C. The effect of DNA CpG methylation on the dynamic conformation of a nucleosome. Biophys. J. 2012, 103, 2502-2512. [CrossRef]

17. Miller, C.A.; Sweatt, J.D. Covalent modification of DNA regulates memory formation. Neuron 2007, 53, 857-869. [CrossRef] 
18. Okano, M.; Bell, D.W.; Haber, D.A.; Li, E. DNA methyltransferases Dnmt3a and Dnmt3b are essential for de novo methylation and mammalian development. Cell 1999, 99, 247-257. [CrossRef]

19. Liang, G.; Chan, M.F.; Tomigahara, Y.; Tsai, Y.C.; Gonzales, F.A.; Li, E.; Laird, P.W.; Jones, P.A. Cooperativity between DNA methyltransferases in the maintenance methylation of repetitive elements. Mol. Cell Biol. 2002, 22, 480-491. [CrossRef]

20. Reik, W.; Dean, W.; Walter, J. Epigenetic reprogramming in mammalian development. Science 2001, 293, 1089-1093. [CrossRef]

21. Eckhardt, F.; Lewin, J.; Cortese, R.; Rakyan, V.K.; Attwood, J.; Burger, M.; Burton, J.; Cox, T.V.; Davies, R.; Down, T.A.; et al. DNA methylation profiling of human chromosomes 6, 20 and 22. Nat. Genet. 2006, 38, 1378-1385. [CrossRef]

22. Sarter, B.; Long, T.I.; Tsong, W.H.; Koh, W.P.; Yu, M.C.; Laird, P.W. Sex differential in methylation patterns of selected genes in Singapore Chinese. Hum. Genet. 2005, 117, 402-403. [CrossRef] [PubMed]

23. Sandovici, I.; Kassovska-Bratinova, S.; Loredo-Osti, J.C.; Leppert, M.; Suarez, A.; Stewart, R.; Bautista, F.D.; Schiraldi, M.; Sapienza, C. Interindividual variability and parent of origin DNA methylation differences at specific human Alu elements. Hum. Mol. Genet. 2005, 14, 2135-2143. [CrossRef]

24. Fuke, C.; Shimabukuro, M.; Petronis, A.; Sugimoto, J.; Oda, T.; Miura, K.; Miyazaki, T.; Ogura, C.; Okazaki, Y.; Jinno, Y. Age related changes in 5-methylcytosine content in human peripheral leukocytes and placentas: An HPLC-based study. Ann. Hum. Genet. 2004, 68, 196-204. [CrossRef] [PubMed]

25. McCarthy, N.S.; Melton, P.E.; Cadby, G.; Yazar, S.; Franchina, M.; Moses, E.K.; Mackey, D.A.; Hewitt, A.W. Meta-analysis of human methylation data for evidence of sex-specific autosomal patterns. BMC Genom. 2014, 15, 981. [CrossRef] [PubMed]

26. El-Maarri, O.; Becker, T.; Junen, J.; Manzoor, S.S.; Diaz-Lacava, A.; Schwaab, R.; Wienker, T.; Oldenburg, J. Gender specific differences in levels of DNA methylation at selected loci from human total blood: A tendency toward higher methylation levels in males. Hum. Genet. 2007, 122, 505-514. [CrossRef] [PubMed]

27. El-Maarri, O.; Walier, M.; Behne, F.; van Üüm, J.; Singer, H.; Diaz-Lacava, A.; Nüsgen, N.; Niemann, B.; Watzka, M.; Reinsberg, J.; et al. Methylation at global LINE-1 repeats in human blood are affected by gender but not by age or natural hormone cycles. PLOS ONE 2011, 6, e16252. [CrossRef] [PubMed]

28. Yousefi, P.; Huen, K.; Davé, V.; Barcellos, L.; Eskenazi, B.; Holland, N. Sex differences in DNA methylation assessed by $450 \mathrm{~K}$ BeadChip in newborns. BMC Genom. 2015, 16, 911. [CrossRef]

29. Maschietto, M.; Bastos, L.C.; Tahira, A.C.; Bastos, E.P.; Euclydes, V.L.V.; Brentani, A.; Fink, G.; de Baumont, A.; Felipe-Silva, A.; Francisco, R.P.V.; et al. Sex differences in DNA methylation of the cord blood are related to sex-bias psychiatric diseases. Sci. Rep. 2017, 7, 44547. [CrossRef] [PubMed]

30. Dong, Y.; Huang, Y.; Gutin, B.; Raed, A.; Dong, Y.; Zhu, H. Associations between Global DNA Methylation and Telomere Length in Healthy Adolescents. Sci. Rep. 2017, 7, 4210. [CrossRef]

31. Reizel, Y.; Spiro, A.; Sabag, O.; Skversky, Y.; Hecht, M.; Keshet, I.; Berman, B.P.; Cedar, H. Gender-specific postnatal demethylation and establishment of epigenetic memory. Genes Dev. 2015, 29, 923-933. [CrossRef]

32. Drake, A.J.; O'Shaughnessy, P.J.; Bhattacharya, S.; Monteiro, A.; Kerrigan, D.; Goetz, S.; Raab, A.; Rhind, S.M.; Sinclair, K.D.; Meharg, A.A.; et al. In utero exposure to cigarette chemicals induces sex-specific disruption of one-carbon metabolism and DNA methylation in the human fetal liver. BMC Med. 2015, 13, 18. [CrossRef] [PubMed]

33. Xiao, Y.; Word, B.; Starlard-Davenport, A.; Haefele, A.; Lyn-Cook, B.D.; Hammons, G. Age and gender affect DNMT3a and DNMT3b expression in human liver. Cell Biol. Toxicol. 2008, 24, 265-272. [CrossRef] [PubMed]

34. Zhu, Z.Z.; Hou, L.; Bollati, V.; Tarantini, L.; Marinelli, B.; Cantone, L.; Yang, A.S.; Vokonas, P.; Lissowska, J.; Fustinoni, S.; et al. Predictors of global methylation levels in blood DNA of healthy subjects: A combined analysis. Int. J. Epidemiol. 2012, 41, 126-139. [CrossRef] [PubMed]

35. Campesi, I.; Carru, C.; Zinellu, A.; Occhioni, S.; Sanna, M.; Palermo, M.; Tonolo, G.; Mercuro, G.; Franconi, F. Regular cigarette smoking influences the transsulfuration pathway, endothelial function, and inflammation biomarkers in a sex-gender specific manner in healthy young humans. Am. J. Transl. Res. 2013, 5, 497-509. [PubMed]

36. Ikegame, T.; Bundo, M.; Sunaga, F.; Asai, T.; Nishimura, F.; Yoshikawa, A.; Kawamura, Y.; Hibino, H.; Tochigi, M.; Kakiuchi, C.; et al. DNA methylation analysis of BDNF gene promoters in peripheral blood cells of schizophrenia patients. Neurosci. Res. 2013, 77, 208-214. [CrossRef] [PubMed] 
37. Wu, J.Y.; Wang, J.; Lai, J.C.; Cheng, Y.W.; Yeh, K.T.; Wu, T.C.; Chen, C.Y.; Lee, H. Association of O6-methylguanine-DNA methyltransferase (MGMT) promoter methylation with p53 mutation occurrence in non-small cell lung cancer with different histology, gender, and smoking status. Ann. Surg. Oncol. 2008, 15, 3272-3277. [CrossRef]

38. Barlow, D.P.; Bartolomei, M.S. Genomic Imprinting in Mammals. Cold Spring Harb. Perspect. Biol. 2014. [CrossRef]

39. Singmann, P.; Shem-Tov, D.; Wahl, S.; Grallert, H.; Fiorito, G.; Shin, S.Y.; Schramm, K.; Wolf, P.; Kunze, S.; Baran, Y.; et al. Characterization of whole-genome autosomal differences of DNA methylation between men and women. Epigenet. Chromatin 2015, 8, 43.

40. Tobi, E.W.; Lumey, L.H.; Talens, R.P.; Kremer, D.; Putter, H.; Stein, A.D.; Slagboom, P.E.; Heijmans, B.T. DNA methylation differences after exposure to prenatal famine are common and timing- and sex-specific. Hum. Mol. Genet. 2009, 18, 4046-4053. [CrossRef] [PubMed]

41. Ratnu, V.S.; Emami, M.R.; Bredy, T.W. Genetic and epigenetic factors underlying sex differences in the regulation of gene expression in the brain. J. Neurosci. Res. 2017, 95, 301-310. [CrossRef] [PubMed]

42. Kaminsky, Z.; Wang, S.C.; Petronis, A. Complex disease, gender and epigenetics. Ann. Med. 2006, 38, 530-544. [CrossRef] [PubMed]

43. Wang, R.; Xin, M.; Li, Y.; Zhang, P.; Zhang, M. The Functions of Histone Modification Enzymes in Cancer. Curr. Protein Pept. Sci. 2016, 17, 438-445. [CrossRef] [PubMed]

44. Chrun, E.S.; Modolo, F.; Daniel, F.I. Histone modifications: A review about the presence of this epigenetic phenomenon in carcinogenesis. Pathol. Res. Pract. 2017, 213, 1329-1339. [CrossRef]

45. Esteller, M. Cancer epigenomics: DNA methylomes and histone-modification maps. Nat. Rev. Genet. 2007, 8, 286-298. [CrossRef] [PubMed]

46. Ferlay, J.E.M.; Lam, F.; Colombet, M.; Mery, L.; Piñeros, M.; Znaor, A.; Soerjomataram, I.; Bray, F. Global Cancer Observatory: Cancer Today. Available online: http://gco.iarc.fr/today/home (accessed on 28 January 2019).

47. Ferlay, J.C.M.; Soerjomataram, I.; Mathers, C.; Parkin, D.M.; Piñeros, M.; Znaor, A.; Bray, F. Estimating the global cancer incidence and mortality in 2018: GLOBOCAN sources and methods. Int. J. Cancer 2018. [CrossRef] [PubMed]

48. Ben-Batalla, I.; Vargas-Delgado, M.E.; Meier, L.; Loges, S. Sexual dimorphism in solid and hematological malignancies. Semin. Immunopathol. 2018. [CrossRef]

49. Heller, G.; Zielinski, C.C.; Zochbauer-Muller, S. Lung cancer: From single-gene methylation to methylome profiling. Cancer Metastasis Rev. 2010, 29, 95-107. [CrossRef] [PubMed]

50. Bjaanaes, M.M.; Fleischer, T.; Halvorsen, A.R.; Daunay, A.; Busato, F.; Solberg, S.; Jørgensen, L.; Kure, E.; Edvardsen, H.; Børresen-Dale, A.L.; et al. Genome-wide DNA methylation analyses in lung adenocarcinomas: Association with EGFR, KRAS and TP53 mutation status, gene expression and prognosis. Mol. Oncol. 2016, 10, 330-343. [CrossRef]

51. Carter, C.A.; Zeman, K.; Day, R.M.; Richard, P.; Oronsky, A.; Oronsky, N.; Lybeck, M.; Scicinski, J.; Oronsky, B. Addressing the elephant in the room, therapeutic resistance in non-small cell lung cancer, with epigenetic therapies. Oncotarget 2016, 7, 40781-40791. [CrossRef] [PubMed]

52. Sharma, S.V.; Lee, D.Y.; Li, B.; Quinlan, M.P.; Takahashi, F.; Maheswaran, S.; McDermott, U.; Azizian, N.; Zou, L.; Fischbach, M.A.; et al. A chromatin-mediated reversible drug-tolerant state in cancer cell subpopulations. Cell 2010, 141, 69-80. [CrossRef] [PubMed]

53. Forde, P.; Brahmer, M.J.R.; Kelly, R.J. New strategies in lung cancer: Epigenetic therapy for non-small cell lung cancer. Clin. Cancer Res. 2014, 20, 2244-2248. [CrossRef] [PubMed]

54. Timp, W.; Feinberg, A.P. Cancer as a dysregulated epigenome allowing cellular growth advantage at the expense of the host. Nat. Rev. Cancer 2013, 13, 497-510. [CrossRef] [PubMed]

55. Chatterjee, A.; Rodger, E.J.; Eccles, M.R. Epigenetic drivers of tumourigenesis and cancer metastasis. Semin. Cancer Biol. 2017, 51, 149-159. [CrossRef] [PubMed]

56. Langevin, S.M.; Kratzke, R.A.; Kelsey, K.T. Epigenetics of lung cancer. Transl. Res. 2015, 165, 74-90. [CrossRef] [PubMed]

57. Lao, V.V.; Grady, W.M. Epigenetics and colorectal cancer. Nat. Rev. Gastroenterol. Hepatol. 2011, 8, 686-700. [CrossRef] 
58. Liu, S.V.; Fabbri, M.; Gitlitz, B.J.; Laird-Offringa, I.A. Epigenetic therapy in lung cancer. Front. Oncol. 2013, 3, 135. [CrossRef]

59. Byler, S.; Goldgar, S.; Heerboth, S.; Leary, M.; Housman, G.; Moulton, K.; Sarkar, S. Genetic and epigenetic aspects of breast cancer progression and therapy. Anticancer Res. 2014, 34, 1071-1077.

60. Fang, J.; Zhang, H.; Jin, S. Epigenetics and cervical cancer: From pathogenesis to therapy. Tumour Biol. 2014, 35, 5083-5093. [CrossRef]

61. Oronsky, B.; Oronsky, N.; Scicinski, J.; Fanger, G.; Lybeck, M.; Reid, T. Rewriting the epigenetic code for tumor resensitization: A review. Transl. Oncol. 2014, 7, 626-631. [CrossRef]

62. Jones, A.P.; Laird, P.W. Cancer-epigenetics comes of age. Nat. Genet. 1999, 21, 163. [CrossRef]

63. Baylin, B.S.; Herman, J.G. DNA hypermethylation in tumorigenesis: Epigenetics joins genetics. Trends Genet. 2000, 16, 168-174. [CrossRef]

64. Baylin, S.B.; Esteller, M.; Rountree, M.R.; Bachman, K.E.; Schuebel, K.; Herman, J.G. Aberrant patterns of DNA methylation, chromatin formation and gene expression in cancer. Hum. Mol. Genet. 2001, 10, 687-692. [CrossRef] [PubMed]

65. Toyooka, S.; Toyooka, K.O.; Maruyama, R.; Virmani, A.K.; Girard, L.; Miyajima, K.; Harada, K.; Ariyoshi, Y.; Takahashi, T.; Sugio, K.; et al. DNA methylation profiles of lung tumors. Mol. Cancer Ther. 2001, 1, 61-67. [PubMed]

66. Vaz, M.; Hwang, S.Y.; Kagiampakis, I.; Phallen, J.; Patil, A.; O’Hagan, H.M.; Murphy, L.; Zahnow, C.Y.; Gabrielson, E.; Velculescu, V.E.; et al. Chronic Cigarette Smoke-Induced Epigenomic Changes Precede Sensitization of Bronchial Epithelial Cells to Single-Step Transformation by KRAS Mutations. Cancer Cell 2017, 32, 360-376. [CrossRef]

67. Carvalho, R.H.; Hou, J.; Haberle, V.; Aerts, J.; Grosveld, F.; Lenhard, B.; Philipsen, S. Genomewide DNA methylation analysis identifies novel methylated genes in non-small-cell lung carcinomas. J. Thorac. Oncol. 2013, 8, 562-573. [CrossRef] [PubMed]

68. Karlsson, A.; Jönsson, M.; Lauss, M.; Brunnström, H.; Jönsson, P.; Borg, Å.; Jönsson, G.; Ringnér, M.; Planck, M.; Staaf, J. Genome-wide DNA methylation analysis of lung carcinoma reveals one neuroendocrine and four adenocarcinoma epitypes associated with patient outcome. Clin. Cancer Res. 2014, 20, 6127-6140. [CrossRef] [PubMed]

69. Shinjo, K.; Okamoto, Y.; An, B.; Yokoyama, T.; Takeuchi, I.; Fujii, M.; Osada, H.; Usami, N.; Hasegawa, Y.; Ito, H.; et al. Integrated analysis of genetic and epigenetic alterations reveals CpG island methylator phenotype associated with distinct clinical characters of lung adenocarcinoma. Carcinogenesis 2012, 33, 1277-1285. [CrossRef] [PubMed]

70. Ferlay, J.; Soerjomataram, I.; Dikshit, R.; Eser, S.; Mathers, C.; Rebelo, M.; Parkin, D.M.; Forman, D.; Bray, F. Cancer incidence and mortality worldwide: Sources, methods and major patterns in GLOBOCAN 2012. Int. J. Cancer 2015, 136, E359-E386. [CrossRef]

71. Aareleid, T.; Zimmermann, M.L.; Baburin, A.; Innos, K. Divergent trends in lung cancer incidence by gender, age and histological type in Estonia: A nationwide population-based study. BMC Cancer 2017, 17, 596. [CrossRef]

72. STATISTIK AUSTRIA-Krebserkrankungen Luftröhre, Bronchien, Lunge. 2018. Available online: http:/ / www.statistik.at/web_de/statistiken/menschen_und_gesellschaft/gesundheit/krebserkrankungen/ luftroehre_bronchien_lunge/index.html (accessed on 28 January 2019).

73. Meza, R.; Meernik, C.; Jeon, J.; Cote, M.L. Lung cancer incidence trends by gender, race and histology in the United States 1973-2010. PLoS ONE 2015, 10, e0121323. [CrossRef]

74. Franceschini, J.P.; Jamnik, S.; Santoro, I.L. Survival in a cohort of patients with lung cancer: The role of age and gender in prognosis. J. Bras. Pneumol. 2017, 43, 431-436. [CrossRef] [PubMed]

75. Yu, Y.; Liu, H.; Zheng, S.; Ding, Z.; Chen, Z.; Jin, W.; Wang, L.; Wang, Z.; Fei, Y.; Zhang, S.; et al. Gender susceptibility for cigarette smoking-attributable lung cancer: A systematic review and meta-analysis. Lung Cancer 2014, 85, 351-360. [CrossRef]

76. Kovalchik, S.A.; de Matteis, S.; Landi, M.T.; Caporaso, N.E.; Varadhan, R.; Consonni, D.; Bergen, A.W.; Katki, H.A.; Wacholder, S. A regression model for risk difference estimation in population-based case-control studies clarifies gender differences in lung cancer risk of smokers and never smokers. BMC Med. Res. Methodol. 2013, 13, 143. [CrossRef] [PubMed] 
77. Skjefstad, K.; Richardsen, E.; Donnem, T.; Andersen, S.; Kiselev, Y.; Grindstad, T.; Hald, S.M.; Al-Shibli, K.; Bremnes, R.M.; Busund, L.T.; et al. The prognostic role of progesterone receptor expression in non-small cell lung cancer patients: Gender-related impacts and correlation with disease-specific survival. Steroids 2015, 98, 29-36. [CrossRef] [PubMed]

78. Enmark, E.; Pelto-Huikko, M.; Grandien, K.A.J.; Lagercrantz, S.; Lagercrantz, J.; Fried, G.; Nordenskjöld, M.; Gustafsson, J.A. Human estrogen receptor beta-gene structure, chromosomal localization, and expression pattern. J. Clin. Endocrinol. Metab. 1997, 82, 4258-4265.

79. Schwartz, A.G.; Prysak, G.M.; Murphy, V.; Lonardo, F.; Pass, H.; Schwartz, J.; Brooks, S. Nuclear estrogen receptor beta in lung cancer: Expression and survival differences by sex. Clin. Cancer Res. 2005, 11, 7280-7287. [CrossRef] [PubMed]

80. Marquez-Garban, D.C.; Mah, V.; Alavi, M.; Maresh, E.L.; Chen, H.W.; Bagryanova, L.; Horvath, S.; Chia, D.; Garon, E.; Goodglick, L.; et al. Progesterone and estrogen receptor expression and activity in human non-small cell lung cancer. Steroids 2011, 76, 910-920.

81. Lai, J.C.; Cheng, Y.W.; Chiou, H.L.; Wu, M.F.; Chen, C.Y.; Lee, H. Gender difference in estrogen receptor alpha promoter hypermethylation and its prognostic value in non-small cell lung cancer. Int. J. Cancer 2005, 117, 974-980. [CrossRef]

82. Pan, C.; Zhu, G.; Yan, Z.; Zhou, Y.; Liu, Z. Glutathione S-transferase T1 and M1 polymorphisms are associated with lung cancer risk in a gender-specific manner. Oncol. Res. Treat. 2014, 37, 164-169. [CrossRef]

83. Shaw, A.T.; Yeap, B.Y.; Mino-Kenudson, M.; Digumarthy, S.R.; Costa, D.B.; Heist, R.S.; Solomon, B.; Stubbs, H.; Admane, S.; McDermott, U.; et al. Clinical Features and Outcome of Patients With Non-Small-Cell Lung Cancer Who Harbor EML4-ALK. J. Clin. Oncol. 2009, 27, 4247-4253. [CrossRef]

84. Fukuoka, M.; Yano, S.; Giaccone, G.; Tamura, T.; Nakagawa, K.; Douillard, J.Y.; Nishiwaki, Y.; Vansteenkiste, J.; Kudoh, S.; Rischin, D.; et al. Multi-institutional randomized phase II trial of gefitinib for previously treated patients with advanced non-small-cell lung cancer (The IDEAL 1 Trial). J. Clin. Oncol. 2003, 21, 2237-2246. [CrossRef] [PubMed]

85. Mok, T.S.; Wu, Y.L.; Thongprasert, S.; Yang, C.H.; Chu, D.T.; Saijo, N.; Sunpaweravong, P.; Han, B.; Margono, B.; Ichinose, Y.; et al. Gefitinib or carboplatin-paclitaxel in pulmonary adenocarcinoma. $N$. Engl. J. Med. 2009, 361, 947-957. [CrossRef] [PubMed]

86. Leon, J.; Casado, J.; Carazo, Á.; Sanjuán, L.; Maté, A.; Muñoz de Rueda, P.; de la Cueva, P.; Quiles, R.; Ruíz, S.; Ruíz-Extremera, A.; et al. Gender-related invasion differences associated with mRNA expression levels of melatonin membrane receptors in colorectal cancer. Mol. Carcinog. 2012, 51, 608-618. [CrossRef] [PubMed]

87. Slattery, M.L.; Potter, J.D.; Curtin, K.; Edwards, S.; Ma, K.N.; Anderson, K.; Schaffer, D.; Samowitz, W.S. Estrogens reduce and withdrawal of estrogens increase risk of microsatellite instability-positive colon cancer. Cancer Res. 2001, 61, 126-130. [PubMed]

88. Lind, G.E.; Thorstensen, L.; Løvig, T.; Meling, G.I.; Hamelin, R.; Rognum, T.O.; Esteller, M.; Lothe, R.A. A CpG island hypermethylation profile of primary colorectal carcinomas and colon cancer cell lines. Mol. Cancer 2004, 3, 28. [CrossRef] [PubMed]

89. Zheng, S.; Chen, P.; McMillan, A.; Lafuente, A.; Lafuente, M.J.; Ballesta, A.; Trias, M.; Wiencke, J.K. Correlations of partial and extensive methylation at the p14(ARF) locus with reduced mRNA expression in colorectal cancer cell lines and clinicopathological features in primary tumors. Carcinogenesis 2000, 21, 2057-2064. [CrossRef]

90. Ali, R.H.; Marafie, M.J.; Bitar, M.S.; Al-Dousari, F.; Ismael, S.; Haider, H.B.; Al-Ali, W.; Jacob, S.P.; Al-Mulla, F. Gender-associated genomic differences in colorectal cancer: Clinical insight from feminization of male cancer cells. Int. J. Mol. Sci. 2014, 15, 17344-17365. [CrossRef] [PubMed]

91. Mariani, M.; Zannoni, G.F.; Sioletic, S.; Sieber, S.; Martino, C.; Martinelli, E.; Coco, C.; Scambia, G.; Shahabi, S.; Ferlini, C. Gender influences the class III and V beta-tubulin ability to predict poor outcome in colorectal cancer. Clin. Cancer Res. 2012, 18, 2964-2975. [CrossRef]

92. Corso, G.; Velho, S.; Paredes, J.; Pedrazzani, C.; Martins, D.; Milanezi, F.; Pascale, V.; Vindigni, C.; Pinheiro, H.; Leite, M.; et al. Oncogenic mutations in gastric cancer with microsatellite instability. Eur. J. Cancer 2011, 47, 443-451. [CrossRef]

93. Sipponen, P.; Correa, P. Delayed rise in incidence of gastric cancer in females results in unique sex ratio (M/F) pattern: Etiologic hypothesis. Gastric Cancer 2002, 5, 213-219. [CrossRef] 
94. Sheh, A.; Ge, Z.; Parry, N.M.; Muthupalani, S.; Rager, J.E.; Raczynski, A.R.; Mobley, M.W.; McCabe, A.F.; Fry, R.C.; Wang, T.; et al. 17beta-estradiol and tamoxifen prevent gastric cancer by modulating leukocyte recruitment and oncogenic pathways in Helicobacter pylori-infected INS-GAS male mice. Cancer Prev. Res. 2011, 4, 1426-1435. [CrossRef] [PubMed]

95. El-Serag, H.B.; Rudolph, K.L. Hepatocellular carcinoma: Epidemiology and molecular carcinogenesis. Gastroenterology 2007, 132, 2557-2576. [CrossRef] [PubMed]

96. Shimizu, I. Impact of oestrogens on the progression of liver disease. Liver Int. 2003, 23, 63-69. [CrossRef] [PubMed]

97. Zheng, B.; Zhu, Y.J.; Wang, H.Y.; Chen, L. Gender disparity in hepatocellular carcinoma (HCC): Multiple underlying mechanisms. Sci. China Life Sci. 2017, 60, 575-584. [CrossRef]

98. Greif, J.M.; Pezzi, C.M.; Klimberg, V.S.; Bailey, L.; Zuraek, M. Gender differences in breast cancer: Analysis of 13,000 breast cancers in men from the National Cancer Data Base. Ann. Surg. Oncol. 2012, 19, 3199-3204. [CrossRef]

99. Ly, D.; Forman, D.; Ferlay, J.; Brinton, L.A.; Cook, M.B. An International Comparison of Male and Female Breast Cancer Incidence Rates. Int. J. Cancer 2013, 132, 1918-1926. [CrossRef] [PubMed]

100. Dobbs, N.A.; Twelves, C.J.; Gillies, H.; James, C.A.; Harper, P.G.; Rubens, R.D. Gender affects doxorubicin pharmacokinetics in patients with normal liver biochemistry. Cancer Chemother Pharmacol. 1995, 36, 473-476. [CrossRef] [PubMed]

101. Silvestri, V.; Barrowdale, D.; Mulligan, A.M.; Neuhausen, S.L.; Fox, S.; Karlan, B.Y.; Mitchell, G.; James, P.; Thull, D.L.; Zorn, K.K.; et al. Male breast cancer in BRCA1 and BRCA2 mutation carriers: Pathology data from the Consortium of Investigators of Modifiers of BRCA1/2. Breast Cancer Res. 2016, 18, 15. [CrossRef]

102. Anderson, W.F.; Jatoi, I.; Tse, J.; Rosenberg, P.S. Male Breast Cancer: A Population-Based Comparison with Female Breast Cancer. J. Clin. Oncol. 2010, 28, 232-239. [CrossRef]

103. Pinto, R.; Pilato, B.; Ottini, L.; Lambo, R.; Simone, G.; Paradiso, A.; Tommasi, S. Different methylation and microRNA expression pattern in male and female familial breast cancer. J. Cell Physiol. 2013, 228, 1264-1269. [CrossRef]

104. Verde, G.; de Llobet, L.; Wright, R.; Quilez, J.; Peiró, S.; Le Dily, F.; Beato, M. Unliganded Progesterone Receptor Governs Estrogen Receptor Gene Expression by Regulating DNA Methylation in Breast Cancer Cells. Cancers 2018, 10, 371. [CrossRef] [PubMed]

105. Guo, C.; Zhang, X.; Pfeifer, G.P. The tumor suppressor RASSF1A prevents dephosphorylation of the mammalian STE20-like kinases MST1 and MST2. J. Biol. Chem. 2011, 286, 6253-6261. [CrossRef] [PubMed]

106. Dammann, R.; Li, C.; Yoon, J.H.; Chin, P.L.; Bates, S.; Pfeifer, G.P. Epigenetic inactivation of a RAS association domain family protein from the lung tumour suppressor locus 3p21.3. Nat. Genet. 2000, 25, 315-319. [CrossRef] [PubMed]

107. Agathanggelou, A.; Honorio, S.; Macartney, D.P.; Martinez, A.; Dallol, A.; Rader, J.; Fullwood, P.; Chauhan, A.; Walker, R.; Shaw, J.A.; et al. Methylation associated inactivation of RASSF1A from region 3p21.3 in lung, breast and ovarian tumours. Oncogene 2001, 20, 1509-1518. [CrossRef] [PubMed]

108. Dammann, R.; Schagdarsurengin, U.; Liu, L.; Otto, N.; Gimm, O.; Dralle, H.; Boehm, B.O.; Pfeifer, G.P.; Hoang-Vu, C. Frequent RASSF1A promoter hypermethylation and K-ras mutations in pancreatic carcinoma. Oncogene 2003, 22, 3806-3812. [CrossRef]

109. Dong, S.M.; Sun, D.I.; Benoit, N.E.; Kuzmin, I.; Lerman, M.I.; Sidransky, D. Epigenetic inactivation of RASSF1A in head and neck cancer. Clin. Cancer Res. 2003, 9, 3635-3640.

110. Buhmeida, A.; Merdad, A.; El-Maghrabi, J.; Al-Thobaiti, F.; Ata, M.; Bugis, A.; Syrjänen, K.; Abuzenadah, A.; Chaudhary, A.; Gari, M.; et al. RASSF1A methylation is predictive of poor prognosis in female breast cancer in a background of overall low methylation frequency. Anticancer Res. 2011, 31, 2975-2981. [PubMed]

111. Vaissiere, T.; Hung, R.J.; Zaridze, D.; Moukeria, A.; Cuenin, C.; Fasolo, V.; Ferro, G.; Paliwal, A.; Hainaut, P.; Brennan, P.; et al. Quantitative analysis of DNA methylation profiles in lung cancer identifies aberrant DNA methylation of specific genes and its association with gender and cancer risk factors. Cancer Res. 2009, 69, 243-252. [CrossRef] [PubMed]

112. Abouzeid, H.E.; El-mezayen, H.A.; Sharad, H.; Rahman, S.A. Promoter hypermethylation of RASSF1A, MGMT, and HIC-1 genes in benign and malignant colorectal tumors. Tumour Biol. 2011, 32, 845-852. [CrossRef] [PubMed] 
113. Hegi, M.E.; Diserens, A.C.; Gorlia, T.; Hamou, M.F.; de Tribolet, N.; Weller, M.; Kros, J.M.; Hainfellner, J.A.; Mason, W.; Mariani, L.; et al. MGMT gene silencing and benefit from temozolomide in glioblastoma. N. Engl. J. Med. 2005, 352, 997-1003. [CrossRef] [PubMed]

114. Huang, C.C.; Chien, W.P.; Wong, R.H.; Cheng, Y.W.; Chen, M.C.; Lee, H. NAT2 fast acetylator genotype and MGMT promoter methylation may contribute to gender difference in K-RAS mutation occurrence in Taiwanese colorectal cancer. Environ. Mol. Mutagen. 2009, 50, 127-133. [CrossRef] [PubMed]

115. Hong, S.H.; Kim, H.G.; Chung, W.B.; Kim, E.Y.; Lee, J.Y.; Yoon, S.M.; Kwon, J.G.; Sohn, Y.K.; Kwak, E.K.; Kim, J.W. DNA hypermethylation of tumor-related genes in gastric carcinoma. J. Korean Med. Sci. 2005, 20, 236-241. [CrossRef] [PubMed]

116. Heller, G.; Babinsky, V.N.; Ziegler, B.; Weinzierl, M.; Noll, C.; Altenberger, C.; Müllauer, L.; Dekan, G.; Grin, Y.; Lang, G.; et al. Genome-wide CpG island methylation analyses in non-small cell lung cancer patients. Carcinogenesis 2013, 34, 513-521. [CrossRef] [PubMed]

117. Lokk, K.; Vooder, T.; Kolde, R.; Välk, K.; Võsa, U.; Roosipuu, R.; Milani, L.; Fischer, K.; Koltsina, M.; Urgard, E.; et al. Methylation markers of early-stage non-small cell lung cancer. PLoS ONE 2012, 7, e39813. [CrossRef] [PubMed]

118. Moran, A.; Fernández-Marcelo, T.; Carro, J.; de Juan, C.; Pascua, I.; Head, J.; Gómez, A.; Hernando, F.; Torres, A.J.; Benito, M.; et al. Methylation profiling in non-small cell lung cancer: Clinical implications. Int. J. Oncol. 2012, 40, 739-746. [PubMed]

119. Pfeifer, P.G.; Rauch, T.A. DNA methylation patterns in lung carcinomas. Semin. Cancer Biol. 2009, 19, $181-187$. [CrossRef] [PubMed]

120. Zochbauer-Muller, S.; Fong, K.M.; Virmani, A.K.; Geradts, J.; Gazdar, A.F.; Minna, J.D. Aberrant promoter methylation of multiple genes in non-small cell lung cancers. Cancer Res. 2001, 61, 249-255. [PubMed]

121. Toyooka, S.; Maruyama, R.; Toyooka, K.O.; McLerran, D.; Feng, Z.; Fukuyama, Y.; Virmani, A.K.; Zochbauer-Muller, S.; Tsukuda, K.; Sugio, K.; et al. Smoke exposure, histologic type and geography-related differences in the methylation profiles of non-small cell lung cancer. Int. J. Cancer 2003, 103, 153-160. [CrossRef] [PubMed]

122. Zochbauer-Muller, S.; Minna, J.D.; Gazdar, A.F. Aberrant DNA methylation in lung cancer: Biological and clinical implications. Oncologist 2002, 7, 451-457. [CrossRef]

123. Gu, J.; Berman, D.; Lu, C.; Wistuba, I.I.; Roth, J.A.; Frazier, M.; Spitz, M.R.; Wu, X. Aberrant Promoter Methylation Profile and Association with Survival in Patients with Non-Small Cell Lung Cancer. Clin. Cancer Res. 2006, 12, 7329-7338. [CrossRef]

124. Belinsky, S.A.; Nikula, K.J.; Palmisano, W.A.; Michels, R.; Saccomanno, G.; Gabrielson, E.; Baylin, S.B.; Herman, J.G. Aberrant methylation of p16(INK4a) is an early event in lung cancer and a potential biomarker for early diagnosis. Proc. Natl. Acad. Sci. USA 1998, 95, 11891-11896. [CrossRef] [PubMed]

125. Calmon, M.F.; Colombo, J.; Carvalho, F.; Souza, F.P.; José Filho, F.G.; Fukuyama, É.E.; Camargo, A.A.; Caballero, O.L.S.; Tajara, E.H.; Cordeiro, J.A.; et al. Methylation profile of genes CDKN2A (p14 and p16), DAPK1, CDH1, and ADAM23 in head and neck cancer. Cancer Genet. Cytogenet. 2007, 173, 31-37. [CrossRef] [PubMed]

126. Daniunaite, K.; Berezniakovas, A.; Jankevičius, F.; Laurinavičius, A.; Lazutka, J.; Jarmalaitè, S. Frequent methylation of RASSF1 and RARB in urine sediments from patients with early stage prostate cancer. Medicina 2011, 47, 147-153. [PubMed]

127. Jeong, D.H.; Youm, M.Y.; Kim, Y.N.; Lee, K.B.; Sung, M.S.; Yoon, H.K.; Kim, K.T. Promoter methylation of p16, DAPK, CDH1, and TIMP-3 genes in cervical cancer: Correlation with clinicopathologic characteristics. Int. J. Gynecol. Cancer 2006, 16, 1234-1240. [CrossRef] [PubMed]

128. Belinsky, S.A. Gene-promoter hypermethylation as a biomarker in lung cancer. Nat. Rev. Cancer 2004, 4, 707-717. [CrossRef] [PubMed]

129. Kim, D.H.; Kim, J.S.; Ji, Y.I.; Shim, Y.M.; Kim, H.; Han, J.; Park, J. Hypermethylation of RASSF1A promoter is associated with the age at starting smoking and a poor prognosis in primary non-small cell lung cancer. Cancer Res. 2003, 63, 3743-3746. [PubMed]

130. Niklinska, W.; Naumnik, W.; Sulewska, A.; Kozłowski, M.; Pankiewicz, W.; Milewski, R. Prognostic significance of DAPK and RASSF1A promoter hypermethylation in non-small cell lung cancer (NSCLC). Folia Histochem. Cytobiol. 2009, 47, 275-280. [CrossRef] 
131. Zhang, Y.; Wang, R.; Song, H.; Huang, G.; Yi, J.; Zheng, Y.; Wang, J.; Chen, L. Methylation of multiple genes as a candidate biomarker in non-small cell lung cancer. Cancer Lett. 2011, 303, 21-28. [CrossRef]

132. Pastuszak-Lewandoska, D.; Kordiak, J.; Migdalska-Sęk, M.; Czarnecka, K.H.; Antczak, A.; Górski, P.; Nawrot, E.; Kiszałkiewicz, J.M.; Domańska, D.; Brzeziańska-Lasota, E. Quantitative analysis of mRNA expression levels and DNA methylation profiles of three neighboring genes: FUS1, NPRL2/G21 and RASSF1A in non-small cell lung cancer patients. Respir. Res. 2015, 16, 76. [CrossRef]

133. Altenberger, C.; Heller, G.; Ziegler, B.; Tomasich, E.; Marhold, M.; Topakian, T.; Müllauer, L.; Heffeter, P.; Lang, G.; End-Pfützenreuter, A.; et al. SPAG6 and L1TD1 are transcriptionally regulated by DNA methylation in non-small cell lung cancers. Mol. Cancer 2017, 16, 1. [CrossRef]

134. Heller, G.; Altenberger, C.; Schmid, B.; Marhold, M.; Tomasich, E.; Ziegler, B.; Müllauer, L.; Minichsdorfer, C.; Lang, G.; End-Pfützenreuter, A.; et al. DNA methylation transcriptionally regulates the putative tumor cell growth suppressor ZNF677 in non-small cell lung cancers. Oncotarget 2015, 6, 394-408. [CrossRef]

135. Sandoval, J.; Mendez Gonzalez, J.; Nadal, E.; Chen, G.; Carmona, F.J.; Sayols, S.; Moran, S.; Heyn, H.; Vizoso, M.; Gomez, A.; et al. A prognostic DNA methylation signature for stage I non-small-cell lung cancer. J. Clin. Oncol. 2013, 31, 4140-4147. [CrossRef] [PubMed]

136. Xu, X.C.; Sozzi, G.; Lee, J.S.; Lee, J.J.; Pastorino, U.; Pilotti, S.; Kurie, J.M.; Hong, W.K.; Lotan, R. Suppression of retinoic acid receptor beta in non-small-cell lung cancer in vivo: Implications for lung cancer development. J. Natl. Cancer Inst. 1997, 89, 624-629. [CrossRef] [PubMed]

137. Picard, E.; Seguin, C.; Monhoven, N.; Rochette-Egly, C.; Siat, J.; Borrelly, J.; Martinet, Y.; Martinet, N.; Vignaud, J.M. Expression of retinoid receptor genes and proteins in non-small-cell lung cancer. J. Natl. Cancer Inst. 1999, 91, 1059-1066. [CrossRef] [PubMed]

138. Virmani, A.K.; Rathi, A.; Zöchbauer-Müller, S.; Sacchi, N.; Fukuyama, Y.; Bryant, D.; Maitra, A.; Heda, S.; Fong, K.M.; Thunnissen, F.; et al. Promoter methylation and silencing of the retinoic acid receptor-beta gene in lung carcinomas. J. Natl. Cancer Inst. 2000, 92, 1303-1307. [CrossRef] [PubMed]

139. Fong, K.M.; Biesterveld, E.J.; Virmani, A.; Wistuba, I.; Sekido, Y.; Bader, S.A.; Ahmadian, M.; Ong, S.T.; Rassool, F.V.; Zimmerman, P.V.; et al. FHIT and FRA3B 3p14.2 allele loss are common in lung cancer and preneoplastic bronchial lesions and are associated with cancer-related FHIT cDNA splicing aberrations. Cancer Res. 1997, 57, 2256-2267.

140. Sozzi, G.; Veronese, M.L.; Negrini, M.; Baffa, R.; Cotticelli, M.G.; Inoue, H.; Tornielli, S.; Pilotti, S.; de Gregorio, L.; Pastorino, U.; et al. The FHIT gene 3p14.2 is abnormal in lung cancer. Cell 1996, 85, 17-26. [CrossRef]

141. Zochbauer-Muller, S.; Fong, K.M.; Maitra, A.; Lam, S.; Geradts, J.; Ashfaq, R.; Virmani, A.K.; Milchgrub, S.; Gazdar, A.F.; Minna, J.D. 5' CpG island methylation of the FHIT gene is correlated with loss of gene expression in lung and breast cancer. Cancer Res. 2001, 61, 3581-3585.

142. Tessema, M.; Yingling, C.M.; Picchi, M.A.; Wu, G.; Ryba, T.; Lin, Y.; Bungum, A.O.; Edell, E.S.; Spira, A.; Belinsky, S.A. ANK1 Methylation regulates expression of MicroRNA-486-5p and discriminates lung tumors by histology and smoking status. Cancer Lett. 2017, 410, 191-200. [CrossRef]

143. Toyooka, K.O.; Toyooka, S.; Virmani, A.K.; Sathyanarayana, U.G.; Euhus, D.M.; Gilcrease, M.; Minna, J.D.; Gazdar, A.F. Loss of expression and aberrant methylation of the CDH13 (H-cadherin) gene in breast and lung carcinomas. Cancer Res. 2001, 61, 4556-4560.

144. Richter, A.M.; Kiehl, S.; Köger, N.; Breuer, J.; Stiewe, T.; Dammann, R.H. ZAR1 is a novel epigenetically inactivated tumour suppressor in lung cancer. Clin. Epigenet. 2017, 9, 60. [CrossRef] [PubMed]

145. Selamat, S.A.; Chung, B.S.; Girard, L.; Zhang, W.; Zhang, Y.; Campan, M.; Siegmund, K.D.; Koss, M.N.; Hagen, J.A.; Lam, W.L.; et al. Genome-scale analysis of DNA methylation in lung adenocarcinoma and integration with mRNA expression. Genome Res. 2012, 22, 1197-1211. [CrossRef] [PubMed]

146. Lee, K.W.K.; Pausova, Z. Cigarette smoking and DNA methylation. Front. Genet. 2013, 4, 132. [CrossRef] [PubMed]

147. Richmond, R.C.; Suderman, M.; Langdon, R.; Relton, C.L.; Davey Smith, G. DNA methylation as a marker for prenatal smoke exposure in adults. Int. J. Epidemiol. 2018, 47, 1120-1130. [CrossRef] [PubMed]

148. Wiencke, J.K.; Zheng, S.; Lafuente, A.; Lafuente, M.J.; Grudzen, C.; Wrensch, M.R.; Miike, R.; Ballesta, A.; Trias, M. Aberrant methylation of p16INK4a in anatomic and gender-specific subtypes of sporadic colorectal cancer. Cancer Epidemiol. Biomark. Prev. 1999, 8, 501-506. 
149. Bae, J.M.; Kim, J.H.; Cho, N.Y.; Kim, T.Y.; Kang, G.H. Prognostic implication of the CpG island methylator phenotype in colorectal cancers depends on tumour location. Br. J. Cancer 2013, 109, 1004-1012. [CrossRef] [PubMed]

150. Miladi-Abdennadher, I.; Abdelmaksoud-Damak, R.; Ayadi, L.; Khabir, A.; Frikha, F.; Kallel, L.; Frikha, M.; Sellami-Boudawara, T.; Gargouri, A.; Mokdad-Gargouri, R. Aberrant methylation of hMLH1 and p16INK4a in Tunisian patients with sporadic colorectal adenocarcinoma. Biosci. Rep. 2011, 31, 257-264. [CrossRef] [PubMed]

151. Jia, M.; Jansen, L.; Walter, V.; Tagscherer, K.; Roth, W.; Herpel, E.; Kloor, M.; Bläker, H.; Chang-Claude, J.; Brenner, H.; et al. No association of $\mathrm{CpG}$ island methylator phenotype and colorectal cancer survival: Population-based study. Br. J. Cancer 2016, 115, 1359-1366. [CrossRef]

152. Lee, D.W.; Han, S.W.; Cha, Y.; Rhee, Y.Y.; Bae, J.M.; Cho, N.Y.; Lee, K.H.; Kim, T.Y.; Oh, D.Y.; Im, S.A.; et al. Different prognostic effect of $\mathrm{CpG}$ island methylation according to sex in colorectal cancer patients treated with adjuvant FOLFOX. Clin. Epigenet. 2015, 7, 63. [CrossRef]

153. Herman, J.G.; Baylin, S.B. Gene silencing in cancer in association with promoter hypermethylation. N. Engl. J. Med. 2003, 349, 2042-2054. [CrossRef]

154. Das, P.M.; Singal, R. DNA methylation and cancer. J. Clin. Oncol. 2004, 22, 4632-4642. [CrossRef] [PubMed]

155. Toyota, M.; Ahuja, N.; Ohe-Toyota, M.; Herman, J.G.; Baylin, S.B.; Issa, J.P.J. CpG island methylator phenotype in colorectal cancer. Proc. Natl. Acad. Sci. USA 1999, 96, 8681-8686. [CrossRef] [PubMed]

156. Suzuki, M.; Shigematsu, H.; Iizasa, T.; Hiroshima, K.; Nakatani, Y.; Minna, J.D.; Gazdar, A.F.; Fujisawa, T. Exclusive mutation in epidermal growth factor receptor gene, HER-2, and KRAS, and synchronous methylation of nonsmall cell lung cancer. Cancer 2006, 106, 2200-2207. [CrossRef]

157. Liu, Z.; Zhao, J.; Chen, X.F.; Li, W.; Liu, R.; Lei, Z.; Liu, X.; Peng, X.; Xu, K.; Chen, J.; et al. CpG island methylator phenotype involving tumor suppressor genes located on chromosome $3 p$ in non-small cell lung cancer. Lung Cancer 2008, 62, 15-22. [CrossRef] [PubMed]

158. Ma, T.; Li, H.; Sun, M.; Yuan, Y.; Sun, L.P. DNMT1 overexpression predicting gastric carcinogenesis, subsequent progression and prognosis: A meta and bioinformatic analysis. Oncotarget 2017, 8, 96396-96408. [CrossRef] [PubMed]

159. Ksiaa, F.; Ziadi, S.; Dhiab, M.B.; Gacem, R.B.; Trimeche, M. Increased DNA methyltransferase 1 protein expression correlates significantly with intestinal histological type and gender in gastric carcinomas. Adv. Med. Sci. 2015, 60, 50-57. [CrossRef] [PubMed]

160. Sakata, M.; Kitamura, Y.H.; Sakuraba, K.; Goto, T.; Mizukami, H.; Saito, M.; Ishibashi, K.; Kigawa, G.; Nemoto, H.; Sanada, Y.; et al. Methylation of HACE1 in gastric carcinoma. Anticancer Res. 2009, 29, 2231-2233. [PubMed]

161. Cui, Y.; Gao, D.; Linghu, E.; Zhan, Q.; Chen, R.; Brock, M.V.; Herman, J.G.; Guo, M. Epigenetic changes and functional study of HOXA11 in human gastric cancer. Epigenomics 2015, 7, 201-213. [CrossRef]

162. Kang, G.H.; Lee, H.J.; Hwang, K.S.; Lee, S.; Kim, J.H.; Kim, J.S. Aberrant CpG island hypermethylation of chronic gastritis, in relation to aging, gender, intestinal metaplasia, and chronic inflammation. Am. J. Pathol. 2003, 163, 1551-1556. [CrossRef]

163. Min, J.; Choi, B.; Han, T.S.; Lee, H.J.; Kong, S.H.; Suh, Y.S.; Kim, T.H.; Choe, H.N.; Kim, W.H.; Hur, K.; et al. Methylation Levels of LINE-1 As a Useful Marker for Venous Invasion in Both FFPE and Frozen Tumor Tissues of Gastric Cancer. Mol. Cells 2017, 40, 346-354.

164. Wang, Y.; Cheng, J.; Xu, C.; Liu, S.; Jiang, S.; Xu, Q.; Chen, X.; Zhuang, H.; Lu, F. Quantitative methylation analysis reveals gender and age differences in p16INK4a hypermethylation in hepatitis B virus-related hepatocellular carcinoma. Liver Int. 2012, 32, 420-428. [CrossRef] [PubMed]

165. Li, X.; Hui, A.M.; Sun, L.; Hasegawa, K.; Torzilli, G.; Minagawa, M.; Takayama, T.; Makuuchi, M. p16INK4A hypermethylation is associated with hepatitis virus infection, age, and gender in hepatocellular carcinoma. Clin. Cancer Res. 2004, 10, 7484-7489. [CrossRef] [PubMed]

166. Omura, N.; Mizuma, M.; MacGregor, A.; Hong, S.M.; Ayars, M.; Almario, J.A.; Borges, M.; Kanda, M.; Li, A.; Vincent, A.; et al. Overexpression of ankyrin1 promotes pancreatic cancer cell growth. Oncotarget 2016, 7, 34977-34987. [CrossRef] [PubMed] 
167. De Unamuno Bustos, B.; Murria Estal, R.; Pérez Simó, G.; Simarro Farinos, J.; Pujol Marco, C.; Navarro Mira, M.; Alegre de Miquel, V.; Ballester Sánchez, R.; Sabater Marco, V.; Llavador Ros, M.; et al. Aberrant DNA methylation is associated with aggressive clinicopathological features and poor survival in cutaneous melanoma. Br. J. Dermatol. 2017, 179, 394-404. [CrossRef] [PubMed]

168. Ooft, M.L.; van Ipenburg, J.; van Loo, R.; de Jong, R.; Moelans, C.; Braunius, W.; de Bree, R.; van Diest, P.; Koljenović, S.; de Jong, R.B.; et al. Molecular profile of nasopharyngeal carcinoma: Analysing tumour suppressor gene promoter hypermethylation by multiplex ligation-dependent probe amplification. J. Clin. Pathol. 2018, 71, 351-359. [CrossRef]

169. Wang, S.; Huang, Y.; Mu, X.; Qi, T.; Qiao, S.; Lu, Z.; Li, H. DNA methylation is related to the occurrence of breast cancer and is not affected by culture conditions. Mol. Med. Rep. 2018, 17, 7365-7371. [CrossRef] [PubMed]

170. Wen, G.; Wang, H.; Zhong, Z. Associations of RASSF1A, RARbeta, and CDH1 promoter hypermethylation with oral cancer risk: A PRISMA-compliant meta-analysis. Medicine 2018, 97, e9971. [CrossRef]

171. Nguyen, M.; Dobosz, P. New Frontiers in Melanoma Epigenetics-The More We Know, the More We Don't Know. Epigenomes 2017, 1, 3. [CrossRef]

172. Ye, M.; Huang, T.; Li, J.; Zhou, C.; Yang, P.; Ni, C.; Chen, S. Role of CDH13 promoter methylation in the carcinogenesis, progression, and prognosis of colorectal cancer: A systematic meta-analysis under PRISMA guidelines. Medicine 2017, 96, e5956. [CrossRef]

173. Singh, A.N.; Sharma, N. Identification of key pathways and genes with aberrant methylation in prostate cancer using bioinformatics analysis. OncoTargets Ther. 2017, 10, 4925-4933. [CrossRef]

174. Pesek, M.; Kopeckova, M.; Benesova, L.; Meszarosova, A.; Mukensnabl, P.; Bruha, F.; Minarik, M. Clinical significance of hypermethylation status in NSCLC: Evaluation of a 30-gene panel in patients with advanced disease. Anticancer Res. 2011, 31, 4647-4652. [PubMed]

175. Kresovich, J.K.; Gann, P.H.; Erdal, S.; Chen, H.Y.; Argos, M.; Rauscher, G.H. Candidate gene DNA methylation associations with breast cancer characteristics and tumor progression. Epigenomics 2018, 10, 367-378. [CrossRef] [PubMed]

176. Li, J.; Jia, X.F.; Liu, J.; Liu, J.J.; Zhao, H.B. Relationship of EGFR DNA methylation with the severity of non-small cell lung cancer. Genet. Mol. Res. 2015, 14, 11915-11923. [CrossRef] [PubMed]

177. Li, Q.; Ding, L.; Jing, N.; Liu, C.; Yang, Z.; Chen, F.; Hou, L.; Wang, J. Folate deficiency and aberrant DNA methylation and expression of FHIT gene were associated with cervical pathogenesis. Oncol. Lett. 2018, 15, 1963-1972. [CrossRef]

178. Zhang, Y.; Xu, X.; Chen, Z.; Zhao, Z. Association of FHIT expression and FHIT gene hypermethylation with liver cancer risk: A PRISMA-compliant meta-analysis. OncoTargets Ther. 2017, 10, 3083-3093. [CrossRef] [PubMed]

179. Han, Y.; Shi, K.; Zhou, S.J.; Yu, D.P.; Liu, Z.D. The clinicopathological significance of hMLH1 hypermethylation in non-small-cell lung cancer: A meta-analysis and literature review. OncoTargets Ther. 2016, 9, 5081-5090.

180. Hawes, S.E.; Stern, J.E.; Feng, Q.; Wiens, L.W.; Rasey, J.S.; Lu, H.; Kiviat, N.B.; Vesselle, H. DNA hypermethylation of tumors from non-small cell lung cancer (NSCLC) patients is associated with gender and histologic type. Lung Cancer 2010, 69, 172-179. [CrossRef] [PubMed]

181. Romani, M.; Pistillo, M.P.; Banelli, B. Epigenetic Targeting of Glioblastoma. Front. Oncol. $2018,8,448$. [CrossRef] [PubMed]

182. Pabalan, N.; Kunjantarachot, A.; Ruangpratheep, C.; Jarjanazi, H.; Christofolini, D.M.; Barbosa, C.P.; Bianco, B. Potential of RASSF1A promoter methylation as biomarker for endometrial cancer: A systematic review and meta-analysis. Gynecol. Oncol. 2017, 146, 603-608. [CrossRef]

183. Chen, H.; Yang, T.; Lei, Z.; Wang, L.; Yang, H.; Tong, X.; Yang, W.T.; Zhao, J.; Gu, Y.; Chen, Y.; et al. RNF111/Arkadia is regulated by DNA methylation and affects TGF-beta/Smad signaling associated invasion in NSCLC cells. Lung Cancer 2015, 90, 32-40. [CrossRef] [PubMed]

184. Hasegawa, R.; Fujiwara, K.; Obinata, D.; Kawashima, H.; Shinojima, Y.; Igarashi, J.; Wang, X.; Ghosh, S.; Nagase, H.; Takahashi, S. Identification of frequent differentially methylated region in sporadic bladder cancers. Urol. Int. 2015, 94, 479-484. [CrossRef] [PubMed] 
185. Brebi, P.; Hoffstetter, R.; Andana, A.; Ili, C.G.; Saavedra, K.; Viscarra, T.; Retamal, J.; Sanchez, R.; Roa, J.C. Evaluation of ZAR1 and SFRP4 methylation status as potentials biomarkers for diagnosis in cervical cancer: Exploratory study phase I. Biomarkers 2014, 19, 181-188. [CrossRef] [PubMed]

186. Guo, S.; Yan, F.; Xu, J.; Bao, Y.; Zhu, J.; Wang, X.; Wu, J.; Li, Y.; Pu, W.; Liu, Y.; et al. Identification and validation of the methylation biomarkers of non-small cell lung cancer (NSCLC). Clin. Epigenet. 2015, 7, 3. [CrossRef] [PubMed]

187. Brock, M.V.; Hooker, C.M.; Ota-Machida, E.; Han, Y.; Guo, M.; Ames, S.; Glöckner, S.; Piantadosi, S.; Gabrielson, E.; Pridham, G.; et al. DNA methylation markers and early recurrence in stage I lung cancer. $N$. Engl. J. Med. 2008, 358, 1118-1128. [CrossRef] [PubMed]

188. Wu, F.; Lu, M.; Qu, L.; Li, D.Q.; Hu, C.H. DNA methylation of hMLH1 correlates with the clinical response to cisplatin after a surgical resection in Non-small cell lung cancer. Int. J. Clin. Exp. Pathol. 2015, 8, 5457-5463. [PubMed]

189. Weller, M.; Tabatabai, G.; Kästner, B.; Felsberg, J.; Steinbach, J.P.; Wick, A.; Schnell, O.; Hau, P.; Herrlinger, U.; Sabel, M.C.; et al. MGMT Promoter Methylation Is a Strong Prognostic Biomarker for Benefit from Dose-Intensified Temozolomide Rechallenge in Progressive Glioblastoma: The DIRECTOR Trial. Clin. Cancer Res. 2015, 21, 2057-2064. [CrossRef] [PubMed]

190. Hascher, A.; Haase, A.K.; Hebestreit, K.; Rohde, C.; Klein, H.U.; Rius, M.; Jungen, D.; Witten, A.; Stoll, M.; Schulze, I.; et al. DNA methyltransferase inhibition reverses epigenetically embedded phenotypes in lung cancer preferentially affecting polycomb target genes. Clin. Cancer Res. 2014, 20, 814-826. [CrossRef] [PubMed]

191. Schiffmann, I.; Greve, G.; Jung, M.; Lübbert, M. Epigenetic therapy approaches in non-small cell lung cancer: Update and perspectives. Epigenetics 2016, 11, 858-870. [CrossRef] [PubMed]

192. Valdespino, V.; Valdespino, P.M. Potential of epigenetic therapies in the management of solid tumors. Cancer Manag. Res. 2015, 7, 241-251. [CrossRef] [PubMed]

193. Lee, H.Z.; Kwitkowski, V.E.; Del Valle, P.L.; Ricci, M.S.; Saber, H.; Habtemariam, B.A.; Bullock, J.; Bloomquist, E.; Shen, Y.L.; Chen, X.H.; et al. FDA Approval: Belinostat for the Treatment of Patients with Relapsed or Refractory Peripheral T-cell Lymphoma. Clin. Cancer Res. 2015. [CrossRef] [PubMed]

194. Dhanak, D.; Jackson, P. Development and classes of epigenetic drugs for cancer. Biochem. Biophys. Res. Commun. 2014, 455, 58-69. [CrossRef] [PubMed]

195. Vojta, A.; Dobrinić, P.; Tadić, V.; Bočkor, L.; Korać, P.; Julg, B.; Klasić, M.; Zoldoš, V. Repurposing the CRISPR-Cas9 system for targeted DNA methylation. Nucleic Acids Res. 2016, 44, 5615-5628. [CrossRef] [PubMed]

196. McDonald, J.I.; Celik, H.; Rois, L.E.; Fishberger, G.; Fowler, T.; Rees, R.; Kramer, A.; Martens, A.; Edwards, J.R.; Challen, G.A. Reprogrammable CRISPR/Cas9-based system for inducing site-specific DNA methylation. Biol. Open 2016, 5, 866-874. [CrossRef] [PubMed]

197. Enríquez, P. CRISPR-Mediated Epigenome Editing. Yale J. Biol. Med. 2016, 471-486. [CrossRef]

198. Kungulovski, G.; Jeltsch, A. Epigenome Editing: State of the Art, Concepts, and Perspectives. Trends Genet. 2016, 32, 101-113. [CrossRef]

199. Lavender, P.; Kelly, A.; Hendy, E.; McErlean, P. CRISPR-based reagents to study the influence of the epigenome on gene expression. Clin. Exp. Immunol. 2018, 194, 9-16. [CrossRef]

(C) 2019 by the authors. Licensee MDPI, Basel, Switzerland. This article is an open access article distributed under the terms and conditions of the Creative Commons Attribution (CC BY) license (http://creativecommons.org/licenses/by/4.0/). 